\title{
ANXIETY, DEPRESSION, STRESS, EMOTIONALITY AND AGGRESSIVITY - FACTORS THAT MAY INFLUENCE IRRATIONAL ALCOHOL CONSUMPTION AND RISKY SEXUAL BEHAVIOR
}

\author{
DOI: http://doi.org/10.26758/11.1.10
}

Mihaela LUNGU(1), Elena Lucreția NEACȘU (2), Cornelia RADA (3)

All authors of article have contributed equally.

(1) PhD. Student, School of Advanced Studies of the Romanian Academy, "Constantin RădulescuMotru" Institute of Philosophy and Psychology, Department of Psychology, Romanian Academy, Bucharest, Romania;

(2) PhD. Student, "Educational Sciences" Doctoral School of The State Pedagogical University "I. Creangă" from Chișinău, Republic of Moldova; E-mail: lucyneacsu79@yahoo.com

(3) "Francisc I. Rainer" Anthropology Institute of the Romanian Academy, Bucharest, Romania; Email: corneliarada@yahoo.com

Address correspondence to: Mihaela Lungu, Str. Gheorghe Asachi, No. 1, B1. B7, Sc. A, Ap.12, Pitești, 110318, Argeș, Romania. Ph: +40 751072206; E-mail: maylla_lungu@yahoo.com

\begin{abstract}
Objectives. This literature review aimed to reveal the relationship between psychological factors such as anxiety, depression, stress, emotionality and aggression on the one hand, and irrational alcohol consumption and risky sexual activity on the other hand, in students (19-25 years) and adjacent age groups.

Material and methods. The study was conducted by analyzing the literature published between 2010 and 2020. The search was conducted in Romanian and English, in 9 international publications, by the following key phrases and terms, separately or in combination: anxiety, depression, stress, emotionality, aggressiveness, alcohol consumption, drinking motives, binge drinking, sexual behavior, risky sex.

Results. Applying repeated exclusion criteria, 31 articles remained in the analysis. Among these, risk behaviors were rarely analyzed in connection with psychological factors. Most studies that investigate risky behaviors regarding alcohol consumption and sexual activity, address them according to gender, educational level, age groups. Women were more prone to anxiety and depression, but also to show more psychological aggression compared to men who showed more physical aggression, even in sexual activity. Researches included aggression as a behavioral trait, and emotionality has been used as a variable in studies to validate standardized tools. Irrational alcohol consumption has been significantly associated with risky sexual activity and various forms of aggression.

Conclusions. The risk of manifesting and developing depressive and anxiety symptoms is higher in victims of aggression, in people with risky sexual activity, and in consumers of irrational alcohol. In students and young people, stress has high values, contributing to the tendency towards risky behaviors. It is necessary to promote successful coping strategies and mechanisms, both in individual and group level, as well as the development of prevention strategies and therapeutic procedures to improve the listed risk behaviors.
\end{abstract}

Keywords: anxiety, depression, aggression, alcohol consumption, sexual activity. 


\section{Introduction}

health.

The mental balance of people is a condition of normal life as important as physical or somatic

The number of people suffering from anxiety, depression, and stress is constantly increasing worldwide, and young people, teenagers or even children do not seem to have a higher protection factor than adults or the elderly. Research shows that students are a social category highly exposed to high levels of stress, anxiety, and depression (Bryan, Baker, \& Tou, 2017; Tutino, Shaughnessy, \& Ouimet, 2018; McDougall, Langille, Steenbeek, Asbridge, \& Andreou, 2019), and this can lead to aggressive behaviors towards the intimate partner (Davis et al. 2012; Agardh, Tumwine, Asamoah, \& Cantor-Graae, 2012b) or in other situations.

Regarding of risky sexual behavior, there is less research and their strategies differ a lot. The prevalence and transmission of HIV/AIDS and syphilis are still to the attention of the authorities and have been monitored at the level of limited research (Monu et al., 2020), but also of institutions with long-term decision-making and action, such an example being the European Center for Disease Prevention and Control (2019). The results showed that there are parts of the population that are very poorly informed about risky sexual behavior.

The association between risky behaviors and psychological factors occurs most often in scientific studies with medical themes, associated with diseases (Guruprasad, Ramakrishnan, \& Shah, 2015), dysfunctions such as infertility (Yang et al., 2017; Lalinec-Michaud \& Engelsmann, 1984), unhealthy diet (Ahmed, Al-Radhwan, Al-Azmi, \& Al-Beajan, 2014), or special social contexts (Foli, South, Lim, \& Hebdon, 2012; Hebdon, Foli, South, \& Lim, 2012).

Alcohol is one of the most consumed and dangerous psychoactive substances. In the United States, Stahre, Roeber, Kanny, Brewer and Zhang said in 2010 that one in ten deaths at the age of 2064 was due to excessive alcohol use. In 2019, new information emerged, showing that although for teenagers and some young people it was forbidden to buy alcohol, $24 \%$ of $8^{\text {th }}$ graders had already tried alcohol, as well as $77 \%$ of students and $85 \%$ of young people (19-28 years) (Schulenberg et al., 2019).

The 2019 World Health Organization report stated that Romania does not have a written national policy on alcohol consumption (World Health Organization, 2019) and no monitoring system on this behavior, although it is ranked $7^{\text {th }}$ among European countries and ranked $9^{\text {th }}$ in the world with 12.61 annual per capita alcohol consumption (World Health Organization, 2018). Worldwide, the same source reports that there are three million deaths due to alcohol consumption each year, and $40 \%$ of alcohol consumers experienced at least one heavy drinking event per month.

Rada and Ispas (2016), following a study conducted on 1539 young people in Romania, aged between 18 and 30, in 2013 and 2014, argued that heavy episodic/occasional drinking - binge drinking - is a phenomenon that has attracted the attention of researchers in recent years on both adolescence and early youth. The same idea was taken over by Aluja, Lucas, Blanch, and Blanco (2019) in a study conducted on 668 young people in the same age range.

Starting from all this and partially knowing the effects that psychological imbalances can produce personally or in community, the present study aims to broaden the field of knowledge by connecting the results of several scientific studies and to identify areas that require further study.

\section{Material and methods}

Depression and anxiety are among the most common imbalances in the mental system and often prove to be the cause of risky behaviors for people both individually and in the community. Either stress reaches at post-traumatic or acute clinical levels, or is manifested in the form of transient symptoms, it accompanies the life and activity of most people affecting their quality. The present analysis is the scientific base for the study of psychological factors involved in risky behaviors among 
students in Romania. It reveals the state of information accessed in 2020 on the psychological factors such as anxiety, depression, stress, emotionality, and aggressivity in relation to alcohol consumption and sexual activity, especially behaviors considered risky. The research directions of the analysis carried out aimed at: identifying relationships between anxiety, depression, stress, aggressivity, and emotionality in students (19-25 years) and adjacent age groups; exploring the influence of psychological factors associated with risky behaviors regarding alcohol consumption and sexual activity; identifying the need for further research on the influence of anxiety, depression, stress, aggressivity, and emotionality on risky behaviors.

The analysis of the literature was done starting from two directions simultaneously. The first direction of literature analysis followed psychological factors, aiming in particular the relationships between anxiety, depression, stress, aggressivity, and emotionality. The second direction of analysis focused on risky behaviors, tracking alcohol consumption, sexual activity, and harmful physical activity.

A larger volume of publications on this topic was studied, but only materials from verified sources that provided consistent information on the topic were selected for inclusion in the analysis. The primary purpose of the present analysis was to explore the existing volume of information on the influence of personality factors on risky behaviors, and into the background aimed to identify less researched areas, but with the potential to provide relevant information for education, public health policies and psychotherapy.

The next plan of research questions was based on the analysis of specialized studies and their results:

How psychological factors such as anxiety, depression, stress, aggressivity, and emotionality and risky behaviors are defined and characterized? What are the relationships between anxiety, depression, stress, aggressivity, and emotionality explored in students?

What are the influences between the psychological factors mentioned and alcohol consumption and/or harmful sexual activity? Are there also influences of risky behaviors on psychological factors, among students and young people?

What aspects of the relationship between the psychological factors and the risky behaviors mentioned are less researched and could bring valuable information for decision-makers and psychotherapists?

The present research is an analysis of the literature on the relationship between psychological factors such as anxiety, depression, stress, aggressivity, and emotionality, on the one hand, and potentially harmful behaviors related to alcohol consumption and sexual activity, on the other hand.

The study was conducted through the systematic analysis of the scientific literature, published between 2010-2020, including correlation between personality factors and risky behaviors. The process consisted of stages of search, selection, and systematic analysis of scientific articles in relation to the set of indicators and criteria detailed below.

The indicators that formed the basis of the analysis of the research results presented in the selected articles were as follows: a) The presence of some personality factors measured in students and the relations between them; b) The existence of correlations between personality factors and risky behaviors; c) The existence of significant correlations between harmful forms of alcohol consumption and sexual activity.

The search for study publications was done in English and Romanian, the search process was done in the following databases: Sage Journals, APA, BioMed Central, US National Library of Medicine, Journal of Studies on Alcohol and Drugs, ELSEVIER, SpringerLink and ScienceDirect, after the following key phrases and terms, taken separately or in combination: anxiety, depression, stress, emotionality, aggressivity/aggressiveness, alcohol consumption, drinking motives, binge drinking, sexual behavior, risky sex.

The searches were performed between November 2019 and October 2020. 
From the results of the online search, 551 titles and abstracts were reviewed, of which were retained for the analysis of the full publication those that simultaneously met the following criteria: the article was published in the period 2010-2020; presented quantitative or qualitative research results relevant to the purpose of this research (study topic included: anxiety, depression, stress, emotionality, aggressivity, risky sexual behavior, risky alcohol consumption, or a combination thereof), at least one variable measured such behavior; the studies were published in journals or other scientifically verified publications. Figure 1 illustrates the way the concepts in the study were analysed and the relationships between them.

\section{Figure 1.}

Levels of analysis of the literature according to the relationships between the factors studied

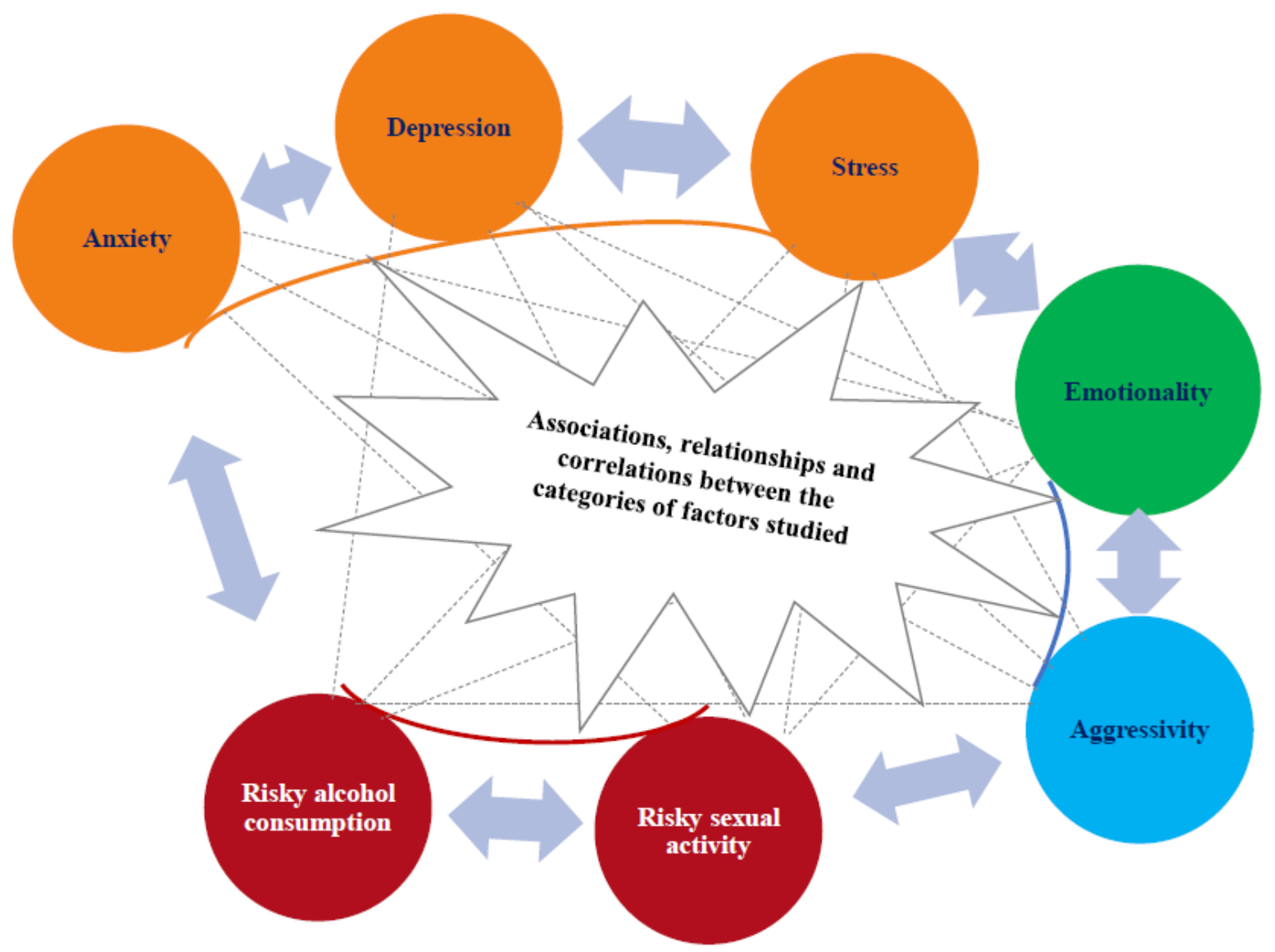

Applying the selection criteria in a first stage, 93 public articles were retained for the analysis of the text. In the next stage, 29 studies were eliminated and which, although they corresponded to the search for keywords and conceptual constructs, were either strictly medical (not psychological), or revealed rather demographic information (translation of the concept of gender, by the word sex). In the third stage, a number of 33 articles were eliminated, the results of which did not provide information relevant to the objectives of the present study. Thus, 31 scientific research articles remained in the final stage, in order to be deepened. A summary of the main elements of analysis for each article is included in Tables 2, 3, 4, and 5. Of the 31 remaining articles in the analysis, 3 dealt with risky behaviors (on alcohol consumption and sexual activity), 11 reported results for the prevalence and implications of psychological factors, and 17 studied both psychological factors and risky behaviors. 


\section{Results}

The table below shows the distribution of research topics in the total number of articles included in the analysis.

\section{Table 1}

Distribution by topics of interest of the studied articles

\begin{tabular}{lcccccc}
\hline & \multicolumn{5}{l}{ Psychological factors } \\
\cline { 2 - 7 } & Anxiety & Depression & Stress & Emotionality & Aggressivity \\
\hline $\begin{array}{l}\text { No association with risky } \\
\text { behaviors }\end{array}$ & 9 & 11 & 4 & 3 & 2 \\
\hline Risky behavior & $\begin{array}{l}\text { Alcohol } \\
\text { consumption }\end{array}$ & 3 & 4 & 0 & 0 & 3 \\
\cline { 2 - 7 } & $\begin{array}{l}\text { Sexual } \\
\text { activity }\end{array}$ & 6 & 11 & 3 & 1 & 5 \\
\hline Total & 18 & 26 & 7 & 4 & 10 \\
\hline
\end{tabular}

In the research studied, risky behaviors were rarely analyzed in connection with psychic components of personality/psychological factors. However, there is scientific concern in this regard. Ngo et al. published in 2018 the results of a survey of 735 young people, according to which $27.2 \%$ of respondents had exercised physical violence in couple, and $16.5 \%$ sexual violence in couple. The results did not show gender differences in the presence of anxiety, nor were they conclusive whether it precedes behavioral violence or vice versa. Shwartz, O'Rourke, and Daoud (2020), however, in a study of 1,055 women in Israel, aged 18-48, on the relationship between postpartum depression and intimate partner violence, found that unplanned pregnancy increases the risk of violence of the intimate partner as well as that of postpartum depression. Significant associations have been found between different risky behaviors such as irrational alcohol consumption and potentially harmful sexual activity (Davis et al., 2012; Choudhry, Agardh, Stafström, \& Östergren, 2014), but less in relation to psychological components.

In a multimodal, predominantly qualitative study, Lloyd, af Klinteberg, and DeMarinis, (2017) claimed that in Sweden, after 2004, young people were the largest group of psychiatric patients. In Australia, 20\% -25\% of young people between the ages of 12 and 25 were estimated to suffer from mental health problems as published in 2019 by Masters, Zimmer-Gembeck, and Farrell, in a study conducted on 391 Australian students. Similar estimates have been made for Western Europe and the United States. Predominant symptoms of anxiety and depression were found more in adolescent girls than in boys, more in women than in men (Masters et al. 2019; Lloyd et al., 2017; ul Haq, Irum Sajjad Dar, Aslam, \& Mahmood, 2018). Lloyd et al. (2017) conducted a study on 53 women between the ages of 21 and 25 who were in treatment or waiting within a psychotherapy clinic, and found that participants with high scores on depression had a negative concept about themselves and the lack or inability to use existential resources (concept about self and world, religion, ontological security, etc.).

ul Haq et al. published in 2018 the results of a study conducted in 2017 on 361 students at Punjab University in Lahore, India. Exploring the levels of anxiety, depression and stress related to various demographic factors, they found that male participants were more anxious, depressed and stressed compared to female, students who reported parents with medium and high educational instruction had fewer symptoms and stated that there were higher levels of anxiety where the participant's father was educated below the high school level.

Defined as anticipation of danger and characterized by muscle tension, alertness, necessary to prepare for an expected danger, as well as through avoidance - cautious behavior (American 
Psychiatric Association, 2016, p.189), anxiety is one of the most common conditions. Unlike fear, long-term anticipations of anxiety refer to negative events, which are usually (not exclusively) psychological in nature (Lovibond \& Lovibond, 1995). For the present research, articles containing any of the following categories were searched and analyzed: social anxiety disorder/social phobia, agoraphobia, generalized anxiety disorder, nonspecific anxiety disorder, combinations thereof, symptoms or manifestations whether evaluated clinically or only in research purpose.

"Depression seems to be a state characterized mainly by a low level of self-esteem and initiative, associated with the perception of a low probability of achieving significant personal goals for the individual" (Lovibond \& Lovibond, 1995, p. 31). In the present study were included all forms of depression according to the American Psychiatric Association (2016, p. 155-188), but also specific symptoms or manifestations.

Mutalik, Moni, Choudhari, and Bhogale, in a study published in 2016, in which they explored depression, anxiety and stress in students in Bagalkot, India, found high levels in all three measured parameters. In Canada, it has been estimated that $8 \%$ of people over the age of 18 will experience depression at some point in their lives. Also, $60 \%$ of respondents to a study of University of Alberta students reported depressive symptoms (McDougall et al. 2019). The same study mentioned above, published in 2018 by ul Haq and his collaborators, showed that the symptoms of depression and stress have higher values in students living with family than those living alone or with friends and that those coming from illiterate mothers have higher levels of anxiety also.

According to the longitudinal study published in 2019 (Carney et al., 2019) and conducted on 662 soldiers over 18 years of age in the United States, infected with HIV, found that those with clinically diagnosed depression reported the lowest condom use in sexual intercourse with new partners compared to those with mild depressive symptoms. Depression seems to be an important factor in choosing risky behaviors in students as well. It may influence the decision to drop out of university, as mentioned by McDougall et al. in 2019, in a study conducted on 6,639 Canadian female students under the age of 30 . "Young adults are more vulnerable to depression and stress being in a period of transition of identity formation" (ul Haq et al., 2018, p. 1). Other researchers have concluded that depression is the most common mental disorder in students.

From a wider range of disorders, the general term of stress "can be conceived as a persistent state of hyperactivation that reflects the difficulty of coping with the difficult demands of life" (Lovibond \& Lovibond, 1995, p. 32). Psychological disorder increasingly present in postmodern society, stress, in its various forms, accompanies the individual at all stages of age. For the present study, attention was paid to all forms of stress included in studies on young people (18-25 years), teenagers or adults.

Post-traumatic stress disorder and depression have been associated with intimate partner violence in men in South Africa as well as in developed countries, as Breet, Seedat, and Kagee mentioned in an article published in 2019. The article is the result of a cross-sectional study conducted on 221 HIV/AIDS survivors. Psychological imbalances and poor mental health can be risk factors for aggressivity. Irritability and anger, as symptoms associated with post-traumatic stress disorder, may increase the likelihood of committing intimate partner violence (Breet et al., 2019). The same study revealed that men who reported more severe symptoms of post-traumatic stress reported 3 times more sexual coercion (committed), while women who reported more severe symptoms of posttraumatic stress disorder were 3 times more likely to commit psychological aggression.

Ahmed et al., in a study published in 2014, conducted on 407 students at the University of Kuwait, over the age of 18 , found that stressed female students had a significantly higher tendency than boys to choose unhealthy food.

As an infinitum continuum, the psychological factor emotionality designates the dynamics of the person's affective spectrum, polarizing from "emotional stability, or, at the opposite pole, a person's neuroticism" (Fahrenberg, Hampel, \& Selg, 2001, p. 45). 
The increased risk of psychological pathology has been associated with emotional disorders (Masters et al., 2019). Emotionality has also been described as "the ease with which emotions are aroused", defining negative emotionality as the experience of the generally negative environment of individuals interacting with other people (Wolff \& Baglivio, 2017, p.5). Analyzing a database of 27,720 juvenile delinquents who completed the sanctioning service in Florida, Wolff and Baglivio found that hostile childhood experiences are activated in the form of negative emotionality. Moreover, they said about children with a predominantly negative perception of others and the environment and those whose (negative) emotions are easier to activate, that they were more likely to engage in antisocial and therefore risky behaviors.

Aggressivity refers to that personality factor characterized either by self-control or by "a high level of spontaneous aggressivity, (...) a general state of hostility towards others and towards the events they face" (Fahrenberg et al., 2001, p. 32).

Although exposure to violence, as a control, may not differ by gender, a 2005 study of 1,220 students in Uganda (Agardh et al., 2012.b) found that symptoms of mental imbalance could be expressed differently. This was relevant in a broader conceptual context, with women experiencing more sexual violence and men experiencing more physical aggressivity. Brett et al. in 2019 showed that when analyzing the tendency to act aggressively, men are more prone to physical aggressivity while women are more prone to psychological aggressivity. In Romania, following a study of 869 respondents between 18 and 75 years old, Rada (2014) found that psychological abuse of men against women was the most common type of reported violence, and 35\% of respondents had witnessed parental violence during childhood.

A study carried out in Romania between 2014-2015 among 836 young people aged 19-23 years living in a romantic relationship revealed that men perceived significantly higher levels of aggressiveness in couple than women. The most surprising result showed that "men were three times more exposed to forced sexual intercourse than women" (Faludi, 2018).

In teenagers, experiencing and committing violence in a cogeneration context (with colleagues and/or couple) amplifies the risk of internalizing symptoms, as found by Garthe, Sullivan, and Behrhorst (2018), in a study conducted on 1,087 teenagers in disadvantaged areas of the United States of America, achieved through the education system.

Only one of the reviewed and studied studies concerns aggressivity as a personality factor (Fahrenberg et al., 2001), the vast majority considering aggressivity as a type of behavior (aggressivity, violence; physical or mental). Lloyd et al. (2017) found that participants with high scores on depression also recorded high scores on inhibiting aggressivity.

For most states, the mental health of citizens has become one of the priority directions of public health policies. Even in some African countries, the national strategic health plan contains aspects of mental health, as shown by Agardh, Cantor-Graae and Ostergren (2012a).

The present study considered the following potentially harmful behaviors: irrational alcohol consumption, risky sexual activity and sedentary lifestyle, later extended to the dimensions of physical activity.

Alcohol consumption is one of the factors with a great influence on the social group and society in general. Kilwein and Looby in 2018 reported reasons for socializing for alcohol consumption, following a study of 108 students, aged 18 to 24, in the central-western United States. The research was supported a year later by Looby, Bravo, Kilwein, Zimmerman and Pearson in 2019, who found similar conclusions, conducting a research on 2,039 students from 10 universities in the United States, with an average age of 19.79 years. The influence of colleagues/ cogeneration rather than parents was also reported by Rada and Ispas (2016).

Understanding the risks associated with sexual activity requires both a psycho-social and a psycho-medical approach. The definition of sexual health according to the World Health Organization: "A state of physical, emotional, mental and social well-being in relation to sexuality; 
it is not merely the absence of disease, dysfunction or infirmity" (Glasier, Gülmezoglu, Schmid, Moreno, \& Van Look, 2006, p. 1596).

In order to determine the sexual quality of a person's life, it is necessary to consider the subjective interpretation of personal experiences and satisfaction. Tutino et al., in a study of 306 students (boys), published in 2018, concluded that sexual arousal could be the most sensitive dimension of sexual functionality in the presence of mental health deficiencies. Another finding of the study was that mental health difficulties may have a greater impact on men's sexual function and quality of life compared to frequency. "Sexual victimization and depression are common in university campuses, especially for women" (McDougall et al., 2019, p. 1).

Risky alcohol consumption is viewed both in terms of the potential harm to human individuals and the destruction of goods that may result from it. Its measurement is made both quantitatively based on an international standard related to culture - Standard Unit of alcohol and as a frequency. Exceeding 4 standard units for women and 5 standard units for men on a single occasion is considered dangerous.

The standard unit (US) of alcohol consumption is also controversial, especially in relation to the country/culture in which the research is carried out: in France - contains $10 \mathrm{~g}$ of pure alcohol, as explained by Costa et al. (2020) in a study conducted between 2016-2018, in France, on 179 subjects over 18 years of age. In Romania, Ministry of Health, National Institute of Public Health, National Center for Health Assessment and Promotion and Sibiu Regional Center for Public Health (Ministerul Sănătății, Institutul Național de Sănătate Publică, Centrul Național de Evaluare și Promovare a Stării de Sănătate și Centrul Regional de Sănătate Publică, Sibiu, 2019) established the standard unit of alcohol consumption at $12 \mathrm{~g}$ of pure alcohol. Both episodes of excessive drinking and sexual risks are behaviors with specific traits, related to culture (Petrova et al., 2019).

Carney et al. found in a study published in 2019 on 662 active HIV-infected soldiers in the United States that consumption of alcohol is a high-risk factor for respondents with recent onset of depressive symptoms. They concluded that there is a linear relationship between daily alcohol consumption and the increased risk of engaging in harmful sexual behaviors.

Like other researchers, Choudhry et al., in 2014, concluded, based on a cross-sectional study conducted on 1,954 students in Uganda, that a possible explanation for the association of alcohol consumption with sexual activity and having multiple sexual partners would be that individuals who believe that alcohol will make them less agitated, more sexually uninhibited, and those who are more at ease in a potentially sexual situation are more likely to drink before a possible sexual interaction in certain social contexts (in a bar, at a meeting, or party).

In some circumstances, the risks associated with sexual activity can be multiple and are studied according to national priorities or contexts. Maina, Orindi, Osindo, and Ziraba (2020), in a study conducted in 2017, on 606 girls aged 10-14 in Kenya, included in the definition of sexual activity, as non-penetrative sexual activities: kissing, holding hands, touching or caressing and spending time together.

Like sexual activity, risky sex is defined in several forms: sexual intercourse with two or more partners in the last 12 months (Choudhry et al., 2014) or even in the last 3 months (Carney et al., 2019); inconsistent condom use with new partners (Carney et al., 2019, Choudhry et al. 2019, Agardh et al. 2012a); sexual assault and/or coercion (Davis et al. 2012; Choudhary, Smith, \& Bossarte, 2012); commercial and intergenerational sex (Choudhry et al., 2014).

Analyzing the gender difference, Breet et al. (2019) found that boys had a tendency almost 2 times higher $(42.9 \%)$ than girls $(23.8 \%)$ to commit sexual coercion. At the same time, Tutino et al. (2018) found that mental health difficulties can have a greater impact on men's sexual functionality and quality of sex life.

McDougall and colleagues (2019) associating risky sex with psychological characteristics found that $6.8 \%$ of study participants, female students under 30 , were victims of unconsented sex 
during university courses. Moreover, they were 2.1 times more likely to be at risk of depression than those who had not experienced sexual victimization.

\section{Discussions}

Looking to identify relationships between anxiety, depression, stress, aggressivity, and emotionality in students (19-25 years old), the following questions were used: How are the psychological factors such as anxiety, depression, stress, aggressivity and emotionality and risky behaviors defined and characterized? What are the relationships between anxiety, depression, stress, aggressivity, and emotionality explored in students?

It was found that the definition of personality factors was mostly common and was based in particular on the fifth edition of the Diagnostic and Statistical Manual of Mental Disorders (American Psychiatric Association, 2016). Most of the studies found addressed either separately or comparatively anxiety, depression, and stress (Mutalik et al., 2016; ul Haq et al. 2018; Tutino et al., 2018; Bryan et al., 2017; Agardh et al. 2012a) and there are many studies that address these issues in relation to intimate partner violence (Yavuzer, Albayrak, \& Kilıçarslan, 2019; Ngo et al., 2018; Agardh et al., 2012b).

The exploration of the influence of psychological factors associated with risky behaviors on alcohol consumption and sexual activity was conducted by looking for answers to the questions: What are the researched influences between the mentioned personality factors and alcohol, sexual activity and harmful physical activity? Are there also influences of risky behaviors on psychological factors? The answer to the second question was negative: none of the studies included in the analysis investigated how the behavior influences the psychological factors.

The most common factor is the aggressivity factor as being investigated in relation to risky behaviors regarding alcohol consumption and sexual activity (Ngo et al. 2018; Davis et al. 2012; Agardh et al., 2012a, 2012b; Breet et al., 2019), but very often in research on psychological factors such as depression and anxiety there are also variables on potentially harmful sexual activity (Kalina et al., 2011; Tutino et al., 2018; Breet et al., 2019; Rada, 2020) and sometimes irrational alcohol consumption (Choudhry et al., 2014; Carney et al., 2019; Agardh et al., 2012a; McDugall et al., 2018).

In order to identify the need for further research on the influence of anxiety, depression, stress, aggressivity and emotionality on risky behaviors, it was studied what aspects of the relationship between psychological factors and the risky behaviors mentioned are less researched and could bring valuable information for decision-makers and psychotherapists. It was found that although there is interest in these associations, the age stages have not yet been studied separately, and in terms of students there are still questions whose answer may influence age-specific educational and therapeutic strategies (Figure 2).

In tables 2, 3, 4, 5 after the Acknowledgments section the analysis of the studies discussed in this article can be consulted by categories as follows: studies that had students as subjects, studies that investigated both psychological factors and risky behaviors, studies that investigated psychological factors unrelated to risky behaviors and studies that investigated only risky behaviors in students. 
Figure 2.

Analysis of the need to deepen and conduct studies on the correlation between risky behaviors and psychological factors

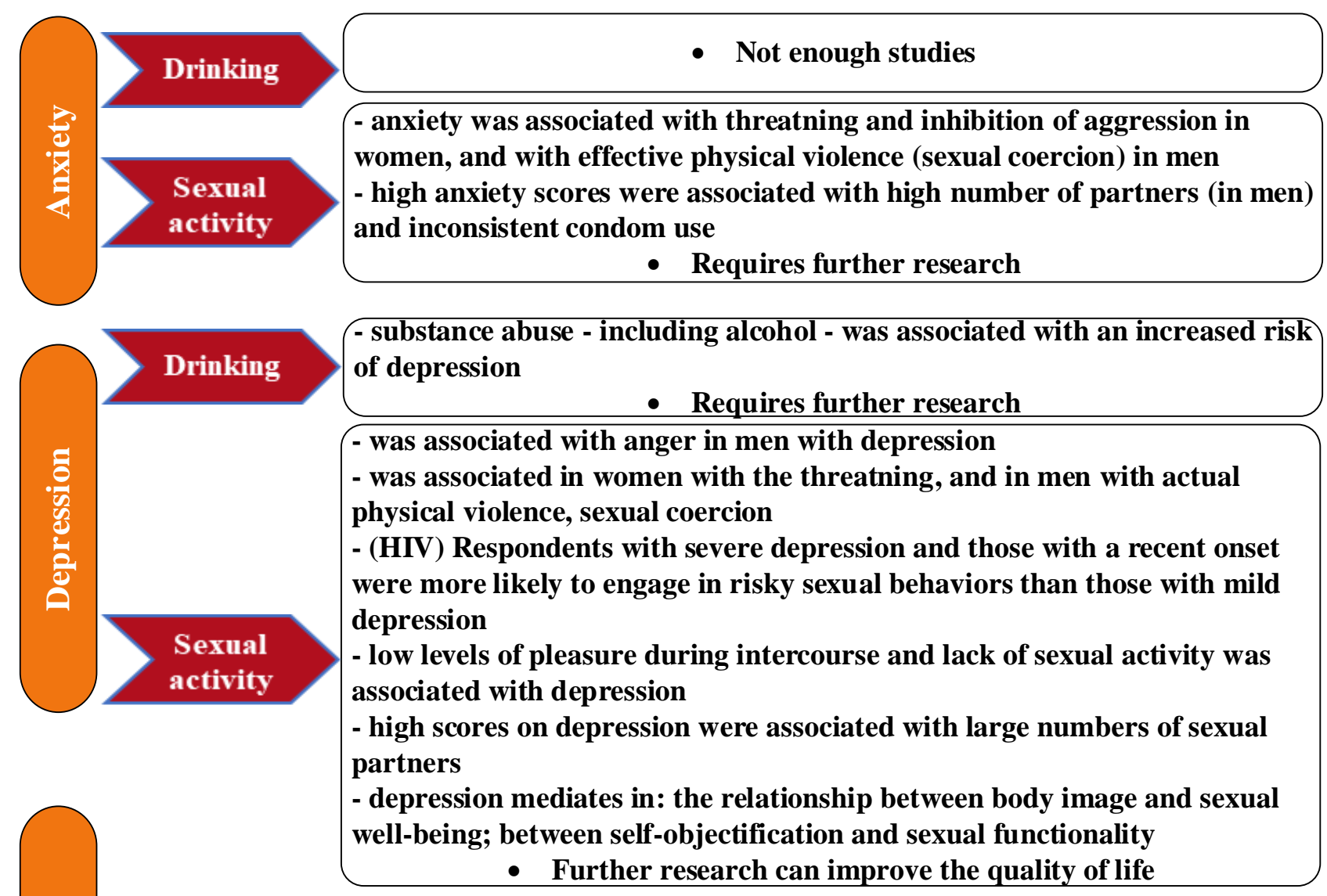

Drinking

Sexual

activity

Drinking

Sexual

activity

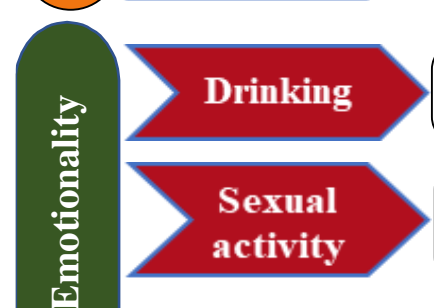

- Not enough studies

- men who reported more severe symptoms of post-traumatic stress, reported 3 times more acts of sexual coercion (committed)

- Not enough studies

\section{- Not enough studies}

- emotional regulation difficulties leaded to poor sexual health in terms of functionality and satisfaction

- Not enough studies

- high alcohol consumption is associated with greater aggression, physical and sexual violence in couples, and with condoms non-usage

Drinking - rapes (by incapacity) were positively associated with alcohol consumption by the aggressor, $51.5 \%$ penetrative sexual assaults involved alcohol consumption

- Requires further research
- a percentage of $42.9 \%$ men and $23.8 \%$ women (out of 210 HIV/ AIDS

survivors, in South Africa) committed sexual coercion

- Not enough studies 


\section{Conclusions}

There are few studies that simultaneously investigate psychological factors and risk behaviors in students, most researching their prevalence. Anxiety and depression are very common and prevalent conditions in students. It was observed that the effects of mental imbalances are consistent and due to them mental health is one of the priorities of health policies. At the same time, although stress is one of the most common and widespread challenges of the $21^{\text {st }}$ century, it does not benefit from in-depth studies on the psychological and behavioral repercussions.

Female subjects seem to tend to experience more anxiety and depression, but also to show more psychological aggressivity compared to male subjects who showed more physical aggressivity, even in sexual activity.

Emotionality as a psychological factor was mostly examined in studies aimed at validating psychodiagnostic tools and less to survey the population or correlate it with other personality or behavioral factors.

Aggressivity has been included in studies most often as a behavioral component (expressive) and not as a psychological factor.

According to the analyzed studies, the mental health difficulties generated sexual dysfunctions (especially in men) and predisposed to risky behaviors for health. Irrational alcohol consumption has been significantly associated with risky sexual activity and various forms of aggression.

Irrational alcohol consumption and risky sexual activity have been mostly investigated as distinct elements or in terms of physical effects on people. They have rarely been associated with personality factors.

Following the research direction coming from risky behaviors to imbalances of psychological factors, it was found that the risk of manifestation and development of symptoms and disorders such as anxiety and depression is higher in victims of aggressivity, people with risky sexual activity and those who consume alcohol irrationally.

The main limitation of the study is that it included insufficient databases in the analysis.

In the subsequent analyzes would be useful to identify articles, studies addressing successful coping strategies and mechanisms at an individual and group level, the development of prevention strategies applicable to teenagers and young people and therapeutic procedures to improve the listed risky behaviors.

\section{Table 2}

Analysis of studies that had students as subjects

\begin{tabular}{llll}
\hline References & Sample & Methodology & $\begin{array}{l}\text { Psychological } \\
\text { factors }\end{array}$ \\
\hline & $\begin{array}{l}537 \text { US volunteer } \\
\text { students, (18-60) }\end{array}$ & Cross-sectional study & \\
& $\begin{array}{l}\text { average 21.75 years, } \\
74.7 \% \text { women, }\end{array}$ & Brief Symptom Inventory-18 (BSI-18), & The Daily Drinking Questionnaire, The \\
& managed online & Rutgers Alcohol Problem Index (RAPI), & anxiety, \\
& (extra course & The Authenticity Inventory-3 (AI-3), The & depression \\
1. Bryan et al., & credits). & Three-Item Loneliness Scale (TILS) &
\end{tabular}

Conclusions and

findings Loneliness correlates positively with poor mental health, anxiety and depression.

6939 students under Online cross-sectional study, 20-25

2. McDougall et 30, Maritime minutes, 44 multiple-choice items, +

al., (2019). Canada Center for Epidemiologic Studies $\quad$ depression 


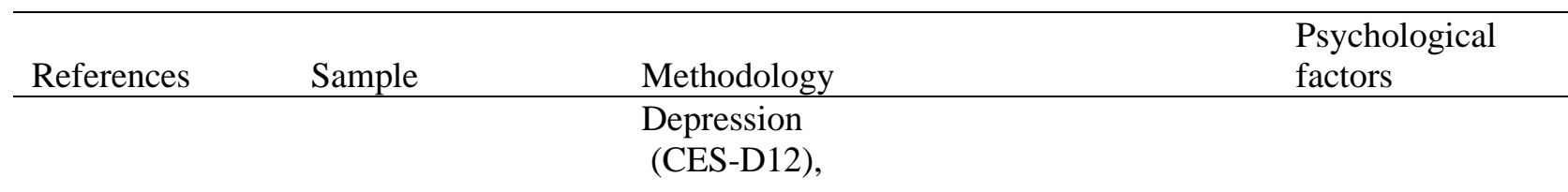

Conclusions and findings

\begin{tabular}{l} 
findings \\
\hline 3. Ngo et al., \\
(2018). \\
Conclusions and \\
findings \\
\\
4. Pelletier, \\
Lytle, and \\
Laska, (2016). \\
Conclusions and \\
findings \\
\\
5. Agardh et al., \\
(2012a). \\
Conclusions and \\
findings
\end{tabular}
findings

A percentage of $36.7 \%$ of students are at risk of depression

Ahimsa Project, Revised Conflict Tactics

Scales (CTS-2), Alcohol Use Disorders

735 young people

Identification Test-Consumption (AUDIT-

(18-25 years old,

C), Five Factor Mindfulness

average 21.5) $270 \mathrm{~F}$

Questionnaire-Short Form, Brief

Inventory

anxiety,

aggressivity

No gender differences in anxiety. It is unclear whether anxiety precedes aggressivity

(mental behavior) or vice versa

441 students under

35 (Body Mass

Cross-sectional study

Index of 20-

Shorr height boards (Irwin Shorr, Olney,

$35 \mathrm{~kg} / \mathrm{m} 2$ ),

community colleges Body Composition Analyzer, Arlington

Minnesota, USA Heights, Cohen Perceived Stress Scale,

stress

High levels of stress have been associated with a high prevalence of overweight and obesity.

980 students $(80 \%$

Cross-sectional study

of the total

self-administered questionnaire (132

university), Uganda

items) + Hopkins Symptoms Checklist-25

and Symptom Checklist-90

anxiety,

High scores in anxiety are associated with high number of partners $(\mathrm{M})$ and inconsistent use of condom (M). High scores in depression $(15 \% \mathrm{M}, 16 \% \mathrm{~F})$ associated with a large number of sexual partners $(\mathrm{F}, \mathrm{M})$, Sexual activity can be related to anger, a strong element in men with depression.

1220 students,

University of

Mbarara, Uganda

Cross-sectional study

(under 23 years and

over), average 23

self-administered questionnaire (132

items), English language, + Hopkins

Symptom

years, $64.6 \% \mathrm{M}$,

Checklist (HSCL-25) and Symptom

6. Agardh et al.,

(2012b).

$35.4 \% \mathrm{~F}$

Checklist-90 (SCL-90)

anxiety/depression

Poor mental health is (anxiety and depression) associated in women with threats, and in men with effective physical violence. Women have higher scores in depression, but the

Conclusions and relationship between depression and violence is similar (F, M). Sexual coercion has been findings significantly associated with poor mental health $(\mathrm{F}, \mathrm{M})$

\section{Validation study (cross-sectional)}

$341(260 \mathrm{~F}, 81 \mathrm{M})$

The Adolescent Resilience Scale, The

7. Cazan, and

Romanian students,

Student-life Stress Inventory (SSI); The

Truța, (2015).

(average age 20.65)

Satisfaction with Life Scale,

stress, emotionality

Conclusions and Stressors worked as mediators between resilience, reaction to stress and life satisfaction. findings Emotional regulation has a mediating effect on reactions to stress.

118 students $(42 \% \quad$ Cross-sectional study

M) in the first year,

8. Mutalik et al., 18-25 years

(2016).

(average 21)

Depression, Anxiety and Stress Scale

(DASS 21), General Health Questionnaire 28 (GHQ 28)

anxiety, depression, stress 


\begin{tabular}{|c|c|c|c|}
\hline References & Sample & Methodology & $\begin{array}{l}\text { Psychological } \\
\text { factors }\end{array}$ \\
\hline $\begin{array}{l}\text { Conclusions and } \\
\text { findings }\end{array}$ & \multicolumn{3}{|c|}{ High levels of depression, anxiety and stress were identified. } \\
\hline \multirow[t]{2}{*}{$\begin{array}{l}\text { 9. ul Haq et al., } \\
\text { (2018). }\end{array}$} & $\begin{array}{l}361 \text { students, } \\
\text { Punjab University, } \\
\text { Lahore, Pakistan }\end{array}$ & $\begin{array}{l}\text { Cross-sectional study } \\
\text { self-administered questionnaire: } \\
\text { demographic data + DASS-21 }\end{array}$ & $\begin{array}{l}\text { anxiety, } \\
\text { depression, stress }\end{array}$ \\
\hline & \multicolumn{3}{|c|}{$\begin{array}{l}\text { Male participants had higher levels of anxiety, depression and stress compared to female } \\
\text { participants. Students with educated parents had fewer symptoms. High levels of } \\
\text { anxiety, depression and stress were found where the mother was illiterate. The level of } \\
\text { anxiety is higher where the father is educated below the level of high school graduation. } \\
\text { Symptoms of depression and stress have higher values in students living with family } \\
\text { than those living alone or with friends (anxiety does not differ). }\end{array}$} \\
\hline \multirow{3}{*}{$\begin{array}{l}\text { 10. Yavuzer et } \\
\text { al., (2019). } \\
\text { Conclusions and } \\
\text { findings }\end{array}$} & $\begin{array}{l}904 \text { students } \\
\text { (average } 25 \text { years) } \\
\text { volunteers } \\
\text { different } \\
\text { specializations }\end{array}$ & $\begin{array}{l}\text { Cross-sectional study } \\
\text { Self-Theory Scale, KAR-YA Aggression } \\
\text { Scale (KAR-YA AS), Beck Depression }\end{array}$ & \\
\hline & $\begin{array}{l}\text { Anatolia (Turkey) } \\
65.7 \% \mathrm{~F}, 34.3 \% \mathrm{M}\end{array}$ & $\begin{array}{l}\text { Inventory, UCLA Loneliness Scale } \\
\text { (UCLA) }\end{array}$ & $\begin{array}{l}\text { depression, } \\
\text { aggression }\end{array}$ \\
\hline & \multicolumn{3}{|c|}{$\begin{array}{l}\text { Loneliness leads to the development (exacerbation) of depression. Depression is a } \\
\text { positive predictor of aggressivity in young adults. }\end{array}$} \\
\hline
\end{tabular}

Table 3

Analysis of studies that researched both psychological factors and risky behaviors

\begin{tabular}{|c|c|c|c|c|}
\hline References & Sample & Methodology & $\begin{array}{l}\text { Psychologic } \\
\text { al factors }\end{array}$ & $\begin{array}{l}\text { Behaviors } \\
\text { approached } \\
\text { through the } \\
\text { risk } \\
\text { dimension }\end{array}$ \\
\hline $\begin{array}{l}\text { 1. Davis et al., } \\
\text { (2012). }\end{array}$ & $\begin{array}{l}225 \text { young men, } 21- \\
35 \text { years old, single, } \\
\text { volunteers, }\end{array}$ & $\begin{array}{l}\text { Cross-sectional, quantitative study } \\
\text { Eligibility conditions, laboratory, } \\
\text { male operator, consent, computer } \\
\text { application: drinking calendar and } \\
\text { history questionnaire, Modified } \\
\text { Sexual Experiences Survey } \\
\text { (MSES), }\end{array}$ & aggressivity & $\begin{array}{l}\text { alcohol } \\
\text { consumption, } \\
\text { sexual } \\
\text { activity }\end{array}$ \\
\hline $\begin{array}{l}\text { Findings } \\
\text { (psychological } \\
\text { factors) }\end{array}$ & \multicolumn{4}{|c|}{$\begin{array}{l}\text { Very consistent association between alcohol consumption and lack of condoms in sexual } \\
\text { assault. Men who have high expectations about the effect of alcohol on risky sex and } \\
\text { aggressivity are most likely to commit sexual assault without a condom under the influence } \\
\text { of alcohol. }\end{array}$} \\
\hline $\begin{array}{l}\text { Findings } \\
\text { (behaviors) }\end{array}$ & \multicolumn{4}{|c|}{$\begin{array}{l}\text { Alcohol consumption considerably reduces condom use. Incapacitated rapes are positively } \\
\text { associated with alcohol consumption by the aggressor. } 51.5 \% \text { of penetrating sexual assaults } \\
\text { involved alcohol consumption and lack of condoms. Very consistent association between } \\
\text { alcohol consumption and lack of condoms in sexual assault. }\end{array}$} \\
\hline $\begin{array}{l}\text { 2. Garthe et } \\
\text { al., (2018). }\end{array}$ & $\begin{array}{l}1087 \text { young people } \\
(51 \% \mathrm{M}), 7^{\text {th }} \text { grade, } \\
\text { ethnic and racial } \\
\text { diversity, } \\
\text { disadvantaged } \\
\text { communities, USA }\end{array}$ & $\begin{array}{l}\text { Secondary data analysis + cross- } \\
\text { sectional study (computer-assisted } \\
\text { interview + teachers' reports on } \\
\text { anxiety and depression in } \\
\text { adolescents. The Problem } \\
\text { Behavior Frequency Scale, }\end{array}$ & $\begin{array}{l}\text { anxiety, } \\
\text { depression, } \\
\text { aggressivity }\end{array}$ & $\begin{array}{l}\text { sexual } \\
\text { activity }\end{array}$ \\
\hline
\end{tabular}




\begin{tabular}{|c|c|c|c|c|}
\hline References & Sample & Methodology & $\begin{array}{l}\text { Psychologic } \\
\text { al factors }\end{array}$ & $\begin{array}{l}\text { Behaviors } \\
\text { approached } \\
\text { through the } \\
\text { risk } \\
\text { dimension }\end{array}$ \\
\hline \multirow{3}{*}{$\begin{array}{l}\text { Findings } \\
\text { (psychological } \\
\text { factors) } \\
\text { Findings } \\
\text { (behaviors) }\end{array}$} & & $\begin{array}{l}\text { adapted Safe Dates aggression } \\
\text { scale, Behavioral Assessment } \\
\text { System for Children (BASC) }\end{array}$ & & \\
\hline & \multicolumn{4}{|c|}{$\begin{array}{l}\text { Teenagers in the category violence against their peers and couples had higher levels of } \\
\text { anxiety than those in the class minor violence. The coincidence of violent relationships (eg: } \\
\text { colleagues aggressivity and victimization, violence against colleagues and peers), } \\
\text { substantially increase the risk of depressive symptoms in young adolescents. }\end{array}$} \\
\hline & Not relevant. & & & \\
\hline $\begin{array}{l}\text { 3.McDougall, } \\
\text { et al., (2019). }\end{array}$ & $\begin{array}{l}6939 \text { female students } \\
\text { under } 30 \text {, Maritime } \\
\text { Canada }\end{array}$ & $\begin{array}{l}\text { Online cross-sectional study, 20- } \\
25 \text { minutes, } 44 \text { multiple-choice } \\
\text { items, + Center for Epidemiologic } \\
\text { Studies Depression (CES-D12), } \\
\text { reminders and incentives, } \\
\text { informed consent }\end{array}$ & depression & $\begin{array}{l}\text { alcohol } \\
\text { consumption, } \\
\text { sexual } \\
\text { activity }\end{array}$ \\
\hline
\end{tabular}

Findings (psychological factors)

A percentage of $36.7 \%$ of the participating female students reveled a risk of depression. Risk behaviors and substance abuse have been associated with an increased risk of Findings depression. A percentage of $6.8 \%$ were victims of non-consensual sex during university (behaviors) courses. The risk of depression was found to be 2.1 times higher than in non-victims.

Cross-sectional, quantitative study Ahimsa Project, Revised Conflict Tactics Scales (CTS-2), Alcohol Use Disorders Identification Test

735 young people (18-25 years, average

4. Ngo et al., (2018). 21.5) $270 \mathrm{~F}$ and Findings (psychological factors)

Findings (behaviors) in couple, also. $465 \mathrm{M}$ - Consumption (AUDIT-C), Five Factor Mindfulness Questionnaire - Short Form, Brief Symptom Inventory committed sexual violence in a couple. anxiety, alcohol aggressivity consumption

No gender differences in anxiety. $27.2 \%$ committed physical violence in a couple, $16.5 \%$

A percentage of $58.6 \%$ of the particiapnts reported alcohol consumption. High alcohol consumption is associated with higer aggressivity of physical violence as of sexual violence 1055 women Arab Cross-sectional study (248) and Jewish (807) Israel, 18-48 female interviewers, trained, Arabic / Hebrew, private rooms, years $(6$ weeks -6 Edinburgh Postnatal Depression

5. Shwartz et months from birth) Scale depression, sexual (EPDS), + specific questions stress activity Findings $\quad$ A percentage of $10.3 \%$ of participants showed postpartum depression (20.7\% Arabs, $7 \%$ (psychological Jews), 36\% exercised violence against their intimate partner. Increased chronic stress factors) produces an indirect effect on postpartum depression.

Findings Unplanned pregnancy increases the risk of intimate partner violence and postpartum (behaviors) depression. 


\begin{tabular}{|c|c|c|c|c|}
\hline References & Sample & Methodology & $\begin{array}{l}\text { Psychologic } \\
\text { al factors }\end{array}$ & $\begin{array}{l}\text { Behaviors } \\
\text { approached } \\
\text { through the } \\
\text { risk } \\
\text { dimension }\end{array}$ \\
\hline \multirow{2}{*}{$\begin{array}{l}\text { 6. Tutino et } \\
\text { al., (2018). } \\
\text { Findings } \\
\text { (psychological } \\
\text { factors) }\end{array}$} & $\begin{array}{l}306 \text { men, students } \\
\text { Ottawa, Canada, } 17- \\
47 \text { years old (average } \\
19.97 \text { ) who reported } \\
\text { sexual activity alone } \\
\text { or with a partner in } \\
\text { the last } 4 \text { weeks }\end{array}$ & $\begin{array}{l}\text { Cross-sectional online study, } \\
\text { online, consent, questionnaire } \\
\text { packet, ASI-3 Difficulties in } \\
\text { Emotion Regulation Scale } \\
\text { (DERS;) Depression Anxiety } \\
\text { Stress } \\
\text { Scales (DASS), Male Sexual } \\
\text { Function Index (MSFI), Sexual } \\
\text { Quality of Life Scale - Male } \\
\text { Version (SQoL-M) and Sexual } \\
\text { Experiences Questionnaire (SEQ), } \\
\text { offset by course credits, }\end{array}$ & $\begin{array}{l}\text { anxiety, } \\
\text { stress, } \\
\text { emotionality }\end{array}$ & $\begin{array}{l}\text { sexual } \\
\text { activity }\end{array}$ \\
\hline & \multicolumn{4}{|c|}{$\begin{array}{l}\text { Greater sensitivity to anxiety leads to more difficulties in emotional regulation). Emotional } \\
\text { regulation moderates the relationship between sensitivity to anxiety and anxiety symptoms. } \\
\text { High mental stress (suffering) leads to poor sexual results. Men with high sensitivity to } \\
\text { anxiety and maladaptive emotional regulation skills: are more likely to develop symptoms } \\
\text { of anxiety and depression, more likely to experience sexual difficulties with functionality } \\
\text { and satisfaction. }\end{array}$} \\
\hline $\begin{array}{l}\text { Findings } \\
\text { (behaviors) }\end{array}$ & \multicolumn{4}{|c|}{$\begin{array}{l}\text { The same factors that make you mentally vulnerable (sensitivity to anxiety, difficulties in } \\
\text { emotional regulation) lead to difficulties in sexual health. Psychological risk factors were } \\
\text { associated with greater difficulties in sexual arousal, orgasm (F, M) and desire (M). Mental } \\
\text { health difficulties can have a greater impact on men's sexual function and quality of sex } \\
\text { compared to frequency. }\end{array}$} \\
\hline \multirow{3}{*}{$\begin{array}{l}\text { 7. Vencill, } \\
\text { Tebbe, and } \\
\text { Garos, (2015). } \\
\text { Findings } \\
\text { (psychological } \\
\text { factors) }\end{array}$} & & $\begin{array}{l}\text { cross-sectional study } \\
\text { General Internalization subscale of } \\
\text { the Sociocultural Attitudes } \\
\text { Toward Appearance Scale } \\
\text { (SATAQ-3), Surveillance } \\
\text { subscale of the Objectified Body } \\
\text { Consciousness Scale (OBCS;), } \\
\text { Depression subscale of the } \\
\text { Depression Anxiety Stress Scale- } \\
21 \text { (DASS-21), Zung Self-Rating } \\
\text { Depression Scale (SRDS;), Center } \\
\text { for Epidemiological Studies- } \\
\text { Depression Scale-Revised } \\
\text { (CESD-R), The Body Exposure } \\
\text { during Sexual Activities }\end{array}$ & & sedentary \\
\hline & $\begin{array}{l}426 \text { heterosexual } \\
\text { women, over } 18 \\
\text { years old }\end{array}$ & $\begin{array}{l}\text { Questionnaire (BESAQ), Sexual } \\
\text { Quality of Life Questionnaire- } \\
\text { Female (SQoL-F) }\end{array}$ & $\begin{array}{l}\text { anxiety, } \\
\text { depression }\end{array}$ & $\begin{array}{l}\text { lifestyle/ } \\
\text { physical } \\
\text { activity }\end{array}$ \\
\hline & \multicolumn{4}{|c|}{$\begin{array}{l}\text { Image anxiety is a mediator in the relationship between body surveillance and sexual well- } \\
\text { being. Depression is a mediator in: the relationship between body surveillance and sexual } \\
\text { well-being, between self-objectification and sexual functionality. }\end{array}$} \\
\hline $\begin{array}{l}\text { Findings } \\
\text { (behaviors) }\end{array}$ & \multicolumn{4}{|c|}{$\begin{array}{l}\text { Image anxiety during sexual activity is negatively associated with sexual physical } \\
\text { functionality. Participants more involved in body monitoring had a higher tendency to } \\
\text { experience depression and image anxiety specific to sexual activity. }\end{array}$} \\
\hline
\end{tabular}




\begin{tabular}{|c|c|c|c|c|}
\hline References & Sample & Methodology & $\begin{array}{l}\text { Psychologic } \\
\text { al factors }\end{array}$ & $\begin{array}{l}\text { Behaviors } \\
\text { approached } \\
\text { through the } \\
\text { risk } \\
\text { dimension }\end{array}$ \\
\hline $\begin{array}{l}\text { 8. Agardh et } \\
\text { al., (2012a). }\end{array}$ & $\begin{array}{l}980 \text { students ( } 80 \% \text { of } \\
\text { the total university), } \\
\text { Uganda }\end{array}$ & $\begin{array}{l}\text { Cross-sectional, quantitative study } \\
\text { self-administered questionnaire } \\
\text { (132 items) + Hopkins Symptoms } \\
\text { Checklist-25 and Symptom } \\
\text { Checklist-90 }\end{array}$ & $\begin{array}{l}\text { anxiety, } \\
\text { depression, } \\
\text { anger }\end{array}$ & $\begin{array}{l}\text { alcohol } \\
\text { consumption, } \\
\text { sexual } \\
\text { activity }\end{array}$ \\
\hline $\begin{array}{l}\text { Findings } \\
\text { (psychological } \\
\text { factors) }\end{array}$ & \multicolumn{4}{|c|}{$\begin{array}{l}\text { High anxiety scores associated with large number of partners }(\mathrm{M}) \text { and inconsistent } \\
\text { condom use }(\mathrm{M}) \text {. High scores in depression }(15 \% \mathrm{M}, 16 \% \mathrm{~F}) \text { were associated with a large } \\
\text { number of sexual partners }(\mathrm{F}, \mathrm{M}) \text {. Sexual activity has been linked to anger, a strong } \\
\text { element in men with depression. }\end{array}$} \\
\hline $\begin{array}{l}\text { Findings } \\
\text { (behaviors) }\end{array}$ & \multicolumn{4}{|c|}{$\begin{array}{l}\text { Strong effect of the high frequency of episodes of excessive drinking, as a measure of } \\
\text { mental health control in terms of sexual activity and the large number of partners. High } \\
\text { scores in anxiety associated with large number of partners (M) and inconsistent use of } \\
\text { condom. }\end{array}$} \\
\hline $\begin{array}{l}\text { 9. Agardh et } \\
\text { al., (2012b). }\end{array}$ & $\begin{array}{l}1220 \text { students, } \\
\text { University of } \\
\text { Mbarara, Uganda } \\
\text { (under } 23 \text { years and } \\
\text { over), average } 23 \\
\text { years, } 64.6 \% \mathrm{M} \\
35.4 \% \mathrm{~F}\end{array}$ & $\begin{array}{l}\text { Cross-sectional, quantitative study } \\
\text { self-administered questionnaire } \\
(132 \text { items), English language }+ \\
\text { Hopkins Symptom } \\
\text { Checklist (HSCL-25) and } \\
\text { Symptom Checklist-90 (SCL-90) }\end{array}$ & $\begin{array}{l}\text { anxiety, } \\
\text { depression, } \\
\text { aggression }\end{array}$ & $\begin{array}{l}\text { sexual } \\
\text { activity }\end{array}$ \\
\hline $\begin{array}{l}\text { Findings } \\
\text { (psychological } \\
\text { factors) }\end{array}$ & \multicolumn{4}{|c|}{$\begin{array}{l}\text { Poor mental health (anxiety and depression) has been associated with women with threats, } \\
\text { and in men with actual physical violence. Women have higher scores in depression, but the } \\
\text { relationship between depression and violence is similar (F, M). Sexual coercion was } \\
\text { significantly associated with poor mental health }(\mathrm{F}, \mathrm{M}) \text {. }\end{array}$} \\
\hline $\begin{array}{l}\text { Findings } \\
\text { (behaviors) }\end{array}$ & \multicolumn{4}{|c|}{$\begin{array}{l}\text { A percentage of } 31.1 \% \text { of respondents experienced sexual coercion (regardless of gender), } \\
\text { a significant association between experiencing sexual coercion and exposure to violence. }\end{array}$} \\
\hline $\begin{array}{l}\text { 10. Breet et al., } \\
\text { (2019). }\end{array}$ & $\begin{array}{l}\text { 210, South Africa, } \\
\text { peri-urban, } \\
\text { HIV/AIDS survivors }\end{array}$ & $\begin{array}{l}\text { Cross-sectional, quantitative study } \\
\text { self-report questionnaire, Conflict } \\
\text { Tactics Scale - Revised (CTS2), } \\
\text { Beck Depression Inventory - } \\
\text { Second Edition (BDI-II), PTSD } \\
\text { Symptom Scale - Self-Report } \\
\text { (PSS-SR), English / Afrikaans / } \\
\text { isiX-hosa language, rewarded } \\
\text { with voucher to the supermarket, }\end{array}$ & $\begin{array}{l}\text { depression, } \\
\text { stress, } \\
\text { aggression }\end{array}$ & $\begin{array}{l}\text { sexual } \\
\text { activity }\end{array}$ \\
\hline $\begin{array}{l}\text { Findings } \\
\text { (psychological } \\
\text { factors) }\end{array}$ & \multicolumn{4}{|c|}{$\begin{array}{l}\text { A percentage of } 48 \% \text { manifested moderate-severe depression (M, F). Women who reported } \\
\text { symptoms of moderate-severe depression tended to report } 4 \text { times more physical } \\
\text { aggressivity (committed). Men who reported more severe symptoms of post-traumatic } \\
\text { stress reported } 3 \text { times more sexual coercion (committed). Women who reported more } \\
\text { severe PTSD symptoms were more than } 3 \text { times more likely to commit psychological } \\
\text { aggressivity. } 44.4 \% \mathrm{M} \text { and } 39.3 \% \mathrm{~F} \text { committed physical aggressivity, } 52.4 \% \mathrm{M} \text { and } 46.4 \% \\
\text { F committed psychological aggressivity }\end{array}$} \\
\hline $\begin{array}{l}\text { Findings } \\
\text { (behaviors) }\end{array}$ & \multicolumn{4}{|c|}{ A percentage of $42.9 \%$ male and $23.8 \%$ female committed sexual coercion. } \\
\hline
\end{tabular}




\begin{tabular}{|c|c|c|c|c|}
\hline References & Sample & Methodology & $\begin{array}{l}\text { Psychologic } \\
\text { al factors }\end{array}$ & $\begin{array}{l}\text { Behaviors } \\
\text { approached } \\
\text { through the } \\
\text { risk } \\
\text { dimension }\end{array}$ \\
\hline $\begin{array}{l}\text { 11. Carney et } \\
\text { al., (2019). }\end{array}$ & $\begin{array}{l}662 \text { active soldiers } \\
\text { (over } 18 \text { years old) } \\
\text { infected with HIV, } \\
\text { USA }\end{array}$ & $\begin{array}{l}\text { Longitudinal study informed } \\
\text { consent, self-reported multiple } \\
\text { measurements Center for } \\
\text { Epidemiological Studies } \\
\text { Depression (CES-D 2006-2010) + } \\
\text { Sexual risk behavior surveys } \\
\text { (RBS 2015) }\end{array}$ & depression & $\begin{array}{l}\text { alcohol } \\
\text { consumption, } \\
\text { sexual } \\
\text { activity }\end{array}$ \\
\hline $\begin{array}{l}\text { Findings } \\
\text { (psychological } \\
\text { factors) }\end{array}$ & \multicolumn{4}{|c|}{$\begin{array}{l}\text { A percentage of } 57 \% \text { of the participants reported mild symptoms of depression, } 26 \% \text { recent } \\
\text { onset, } 17 \% \text { severe depression ( } 90 \% \text { undiagnosed). Participants with clinically diagnosed } \\
\text { depression }(10 \%) \text { reported fewer condom use with new sexual partners than undiagnosed } \\
\text { ones. Those with newly onset depression and severe depression use fewer condoms with } \\
\text { new sexual partners (and more than } 2 \text { in the last } 3 \text { months) than those with reduced } \\
\text { depressive tendencies. }\end{array}$} \\
\hline $\begin{array}{l}\text { Findings } \\
\text { (behaviors) }\end{array}$ & \multicolumn{4}{|c|}{$\begin{array}{l}\text { A linear relationship was found between daily alcohol consumption and increased risk of } \\
\text { engaging in harmful sexual behaviors. Respondents with severe depression and those with } \\
\text { recent onset were more likely to engage in risky sexual behaviors than those with mild } \\
\text { depression. }\end{array}$} \\
\hline $\begin{array}{l}\text { 12. Choudhary } \\
\text { et al., (2012). }\end{array}$ & $\begin{array}{l}61187 \text { adults USA, } \\
\text { (over } 18 \text { years old), } \\
48.75 \% \mathrm{M}, 51.25 \% \\
\mathrm{~F}\end{array}$ & $\begin{array}{l}\text { Cross-sectional, quantitative study } \\
\text { Behavioral Risk Factor } \\
\text { Surveillance System (BRFSS) } \\
\text { questionnaire }\end{array}$ & $\begin{array}{l}\text { anxiety, } \\
\text { depression }\end{array}$ & $\begin{array}{l}\text { sexual } \\
\text { activity }\end{array}$ \\
\hline
\end{tabular}

Findings

(psychological A percentage of 5\% were victims of sexual assault, of which: $8.37 \%$ manifested anxiety factors) disorder, $18.82 \%$ diagnosed depression, $28.28 \%$ diagnosed depression and anxiety.

Findings $\quad$ A percentage of $5.3 \%$ stated that they were victims of sexual abuse $(88.84 \% \mathrm{~F})$. Anxiety (behaviors) and depression had significantly higher values in victims of sexual assault.

Cross-sectional, quantitative

3725 (limited to study, questionnaires addressed in

2318) students, 13- $\quad 2$ consecutive hours (90 minutes).

16 years $(51 \% \mathrm{~F}), \quad$ Self-esteem (Rosenberg);

13. Kalina et schools - towns in Psychological well-being (GHQ12)

alcohol Slovakia

anxiety, sexual al., 92011). Findings $\quad$ Older boys who reported having more frequent sex had higher levels of positive self-esteem, (psychological higher levels of psychological well-being (for those who reported low numbers: higher factors) scores were reported in depression/anxiety, social functioning problems)

A percentage of $48.2 \%$ (108) reported sexual activity after drinking alcohol, $37.5 \%$ without a condom at the last report, sometimes followed by unwanted pregnancy. Of total respondents, 33.9\% (224) had first sexual intercourse, after at least one month of Findings relationship, $19.6 \%$ had $>4$ partners; Reported effects: sexually transmitted diseases, (behaviors) unwanted pregnancy.

\begin{tabular}{|c|c|c|c|}
\hline \multirow{2}{*}{$\begin{array}{l}\text { 14. Maina et } \\
\text { al., (2020). } \\
\text { Findings } \\
\text { (psychological } \\
\text { factors) }\end{array}$} & $\begin{array}{l}606 \text { girls, } 10-14 \\
\text { years old, Nairobi, } \\
\text { Kenya }\end{array}$ & $\begin{array}{l}\text { Longitudinal study (secondary } \\
\text { stage) } \\
\text { face-to-face interview with } \\
\text { trained operators, women, } \\
\text { parental consent }\end{array}$ & $\begin{array}{l}\text { sexual } \\
\text { activity }\end{array}$ \\
\hline & \multicolumn{3}{|c|}{$\begin{array}{l}\text { A percentage of } 60 \% \text { of girls have reported at least one symptom of depression in the last } \\
12 \text { months. Girls with depressive symptoms were more likely to have sexuality in the pattern } \\
\text { "experienced". }\end{array}$} \\
\hline
\end{tabular}




\begin{tabular}{|c|c|c|c|c|}
\hline References & Sample & Methodology & $\begin{array}{l}\text { Psychologic } \\
\text { al factors }\end{array}$ & $\begin{array}{l}\text { Behaviors } \\
\text { approached } \\
\text { through the } \\
\text { risk } \\
\text { dimension }\end{array}$ \\
\hline $\begin{array}{l}\text { Findings } \\
\text { (behaviors) }\end{array}$ & $\begin{array}{l}\text { A percentage of } 13 \% \\
\text { experience. }\end{array}$ & out of the participants reportec & naive or $\exp$ & rienced sexual \\
\hline $\begin{array}{l}\text { 15. Rada, } \\
(2020) \text {. }\end{array}$ & $\begin{array}{l}601 \text { geriatric patients } \\
\text { in a institute, } 55-93 \\
\text { years old (average } \\
67.32 \text { ) }\end{array}$ & $\begin{array}{l}\text { Cross-sectional study } \\
\text { informed consent, The Geriatric } \\
\text { Depression Scale long form } \\
\text { (GDS), }++\end{array}$ & depression & $\begin{array}{l}\text { sexual } \\
\text { activity }\end{array}$ \\
\hline $\begin{array}{l}\text { Findings } \\
\text { (psychological } \\
\text { factors) }\end{array}$ & \multicolumn{4}{|c|}{ Association between those who report sedentary lifestyle and depression were found. } \\
\hline $\begin{array}{l}\text { Findings } \\
\text { (behaviors) }\end{array}$ & \multicolumn{4}{|l|}{ Not relevant. } \\
\hline
\end{tabular}

Table 4

Analysis of studies that researched psychological factors unrelated to risky behaviors

\begin{tabular}{|c|c|c|}
\hline References & Sample & $\begin{array}{l}\text { Psychological } \\
\text { factors }\end{array}$ \\
\hline \multirow{2}{*}{$\begin{array}{l}\text { 1. Bryan et al., } \\
\text { (2017). } \\
\text { Findings } \\
\text { (psychological } \\
\text { factors) }\end{array}$} & $\begin{array}{l}537 \text { US volunteer } \\
\text { students, }(18-60) \text {, } \\
\text { average } 21.75 \text { years, } \\
74.7 \% \text { women, } \\
\text { managed online (extra } \\
\text { course credits). }\end{array}$ & $\begin{array}{l}\text { Cross-sectional, quantitative study } \\
\text { Brief Symptom Inventory-18 (BSI- } \\
\text { 18; } \\
\text { Derogatis, 2000), The Daily Drinking } \\
\text { Questionnaire, The Rutgers Alcohol } \\
\text { Problem Index (RAPI), The } \\
\text { Authenticity Inventory-3 (AI-3), The } \\
\text { Three-Item Loneliness Scale (TILS) }\end{array}$ \\
\hline & \multicolumn{2}{|c|}{ Loneliness positively correlates with poor mental health, anxiety and depression. } \\
\hline \multirow{2}{*}{$\begin{array}{l}\text { 2. Dobson, } \\
\text { Ahnberg } \\
\text { Hopkins, Fata, } \\
\text { Scherrer, and } \\
\text { Allan, (2010). } \\
\text { Findings } \\
\text { (psychological } \\
\text { factors) }\end{array}$} & $\begin{array}{l}\text { High-risk adolescents } \\
\text { (high score on severe } \\
\text { depression but no major } \\
\text { depressive disorder or } \\
\text { current or past manic } \\
\text { episode), Calgary, } \\
\text { Alberta, and Canada. } \\
\text { 25- "Coping with } \\
\text { stress", 21- "Let's talk" }\end{array}$ & $\begin{array}{l}\text { Cross-sectional, quantitative study } \\
\text { Center for Epidemiological } \\
\text { Studies-Depression Scale (CES-D), } \\
\text { Computerized Diagnostic Interview for } \\
\text { Children and Adolescents for DSM-IV, } \\
\text { Mood and Anxiety Symptom Questionnaire } \\
\text { (MASQ), Rosenberg Self-Esteem Scale } \\
\text { (RSES) }\end{array}$ \\
\hline & \multicolumn{2}{|c|}{$\begin{array}{l}\text { The CBT protocol as well as the "Let's talk" protocol reduce the severity of depressive } \\
\text { and anxiety symptoms in high-risk adolescents and increase self-esteem. }\end{array}$} \\
\hline $\begin{array}{l}\text { 3. Bonsaksen } \\
\text { and Lerdal, } \\
\text { (2012). }\end{array}$ & $\begin{array}{l}18(12 \mathrm{M}, 6 \mathrm{~F}) \\
\text { hospitalized psychiatric } \\
\text { patients (average } 7-8 \\
\text { months of treatment), } \\
\text { Oslo, Norway, average } \\
\text { age } 43.7 \text { years. }\end{array}$ & $\begin{array}{l}\text { Cross-sectional, quantitative study } \\
\text { The Global Assessment of Functioning Scale } \\
\text { (GAF), International Physical Activity } \\
\text { Questionnaire (IPAQ), The World Health anxiety, } \\
\text { Organization Quality of Life - BREF depression }\end{array}$ \\
\hline
\end{tabular}




\begin{tabular}{|c|c|c|c|}
\hline References & Sample & Methodology & $\begin{array}{l}\text { Psychological } \\
\text { factors }\end{array}$ \\
\hline & & $\begin{array}{l}\text { (WHOQOL-BREF), The Hospital } \\
\text { and Depression Scale (HADS) }\end{array}$ & nxiety \\
\hline
\end{tabular}

\begin{tabular}{|c|c|}
\hline $\begin{array}{l}\text { Findings } \\
\text { (psychological } \\
\text { factors) }\end{array}$ & $\begin{array}{l}\text { Patients with different diagnoses of schizophrenia reported higher levels of depression } \\
\text { and anxiety. } \\
\text { General levels of physical activity were low and did not seem to relate to quality of life. } \\
\text { Patients with different diagnoses of schizophrenia were more physically active and } \\
\text { reported a lower quality of life. }\end{array}$ \\
\hline $\begin{array}{l}\text { 4. Lloyd et al., } \\
\text { (2017). }\end{array}$ & \begin{tabular}{llll} 
& Multi-modal & \multicolumn{1}{c}{ study, predominantly } \\
& qualitative, semi-structured interview. \\
Quantitative: & Karolinska Scales of \\
$53 \mathrm{~F}, 21-25$ years & Personality (KSP), Multidimensional \\
(average 22.7), & Measurement of Religiousness/Spirituality \\
outpatient & for Use in Health Research, Structural anxiety, \\
psychotherapy clinic, & Analysis of Social Behaviour-Self-Concept depression, \\
Sweden & (SASB),
\end{tabular} \\
\hline
\end{tabular}

Findings $\quad$ High anxiety. Tendency to depression. Participants with high scores in depression had (psychological a negative conception of themselves and a lack or inability to use existential resources. factors) Inhibition of aggressivity.

$27720,(21 \%$ of

juvenile delinquents Data analysis,

5. Wolff and who completed

Baglivio, Community sanction centralized community sanction service

anxiety, (2017). service), Florida database, Full Community Positive depression, Achievement Change Tool (C-PACT) emotionality (Anxiety and depression were included in the negative emotionality). About 50\% of the observed effects of adverse childhood experiences are indirectly activated by negative Findings emotionality. Children with a more negative perception of others and the environment (psychological and those whose (negative) emotions are easier to activate are more likely to engage in factors) antisocial behaviors. $341(260 \mathrm{~F}, 81 \mathrm{M})$

Romanian students, The Adolescent Resilience Scale, The 6. Cazan and different faculties Student-life Stress Inventory (SSI); The Truța, (2015) Findings (psychological Stressors acted as mediators between resilience, reaction to stress, and life satisfaction. factors) Emotional regulation has a mediating effect on stress reactions.

\section{Longitudinal, quantitative study} parental consent, questionnaire applied 4 times, kept 3 (for each year) last year was completed online. The Social Anxiety Scale for Adolescents (SAS-A), The Short Mood

7. Masters et al., (2019).

391 students $(56 \% \mathrm{~F})$ Australia, grades 6-8 (monitored up to 9-11) and Feelings Questionnaire (SMFQ), The Difficulty in Emotion Regulation Scale (DERS), anxiety, depression, emotionality Early emotional disorders associated with symptoms of anxiety and subsequent depression, instead associated with emotional disorders. There is a process of emotional problems in adolescents, in the transition from early to middle adolescence. Lack of

Findings (psychological factors) emotional clarity, non-acceptance of emotional responses, difficulties in controlling impulses, limited access to emotional regulation strategies, and difficulties in engaging in goal-oriented behaviors 


\begin{tabular}{|c|c|c|c|}
\hline References & Sample & \multirow{2}{*}{$\begin{array}{l}\text { Methodology } \\
\text { Informed consent, Depression, Anxiety and } \\
\text { Stress Scale (DASS 21), General Health } \\
\text { Questionnaire 28 (GHQ 28), }\end{array}$} & $\begin{array}{l}\text { chological } \\
\text { tors }\end{array}$ \\
\hline \multirow{2}{*}{$\begin{array}{l}\text { 8. Mutalik, et al. } \\
\text { (2016), May } \\
\text { Findings } \\
\text { (psychological } \\
\text { factors) }\end{array}$} & $\begin{array}{l}118 \text { students }(42 \% \mathrm{M}) \\
\text { in the first year, } 18-25 \\
\text { years (average } 21)\end{array}$ & & $\begin{array}{l}\text { anxiety, } \\
\text { depression, } \\
\text { stress }\end{array}$ \\
\hline & \multicolumn{3}{|c|}{$\begin{array}{l}\text { The level of anxiety was found to be higher than that of depression, followed by stress } \\
\text { (DASS 21). Female respondents had higher levels of emotional distress than male } \\
\text { respondents (GHQ 28). }\end{array}$} \\
\hline $\begin{array}{l}\text { 9. Soleimani et } \\
\text { al., (2017). } \\
\text { October- } \\
\text { November } 2015\end{array}$ & $\begin{array}{l}399 \text { teenagers }(14-19 \\
\text { years old), Qazvin, Iran }\end{array}$ & $\begin{array}{l}\text { Cross-sectional, descriptive study, Revised } \\
\text { Child Anxiety and Depression Scale } \\
\text { (RCADS), Iranian Adolescents Risk-taking } \\
\text { Scale (IARS), }\end{array}$ & $\begin{array}{l}\text { anxiety, } \\
\text { depression }\end{array}$ \\
\hline $\begin{array}{l}\text { Findings } \\
\text { (psychological } \\
\text { factors) }\end{array}$ & \multicolumn{3}{|c|}{$\begin{array}{l}\text { Anxiety and depression significantly predict the occurrence of risky behaviors, along } \\
\text { with: having smoking friends, suicidal ideation, and strong suicidal ideation. }\end{array}$} \\
\hline $\begin{array}{l}\text { 10. ul Haq et al., } \\
\text { (2018). }\end{array}$ & $\begin{array}{l}361 \text { students, Punjab } \\
\text { University, Lahore, } \\
\text { Pakistan }\end{array}$ & $\begin{array}{l}\text { Cross-sectional study } \\
\text { self-administered questionnaire: } \\
\text { demographic data + DASS-21 }\end{array}$ & $\begin{array}{l}\text { anxiety, } \\
\text { depression, } \\
\text { stress }\end{array}$ \\
\hline $\begin{array}{l}\text { Findings } \\
\text { (psychological } \\
\text { factors) }\end{array}$ & \multicolumn{3}{|c|}{$\begin{array}{l}\text { Male participants had higher levels of anxiety, depression and stress compared to female } \\
\text { participants. Students with educated parents had fewer symptoms. Symptoms of } \\
\text { depression and stress have higher values in students living with family than those living } \\
\text { alone or with friends (anxiety is no different). The illiterate mother correlates with high } \\
\text { levels of anxiety, depression, stress. The level of depression is higher where the father } \\
\text { is illiterate. The level of anxiety is higher where the father is educated below the level } \\
\text { of high school graduation. }\end{array}$} \\
\hline $\begin{array}{l}\text { 11. Yavuzer et } \\
\text { al., (2019). }\end{array}$ & $\begin{array}{l}904 \text { students (average } \\
25 \text { years) volunteers, } \\
\text { different specializations } \\
\text { Anatolia (Turkey) } \\
65.7 \% \mathrm{~F}, 34.3 \% \mathrm{M} \\
\end{array}$ & $\begin{array}{l}\text { Transverse sturgeon } \\
\text { Self-Theory Scale, KAR-YA Aggression } \\
\text { Scale (KAR-YA AS), Beck Depression } \\
\text { Inventory, UCLA Loneliness Scale (UCLA) }\end{array}$ & $\begin{array}{l}\text { depression, } \\
\text { aggression }\end{array}$ \\
\hline $\begin{array}{l}\text { Findings } \\
\text { (psychological } \\
\text { factors) }\end{array}$ & \multicolumn{3}{|c|}{$\begin{array}{l}\text { Loneliness leads to the development (exacerbation) of depression. Depression is a } \\
\text { positive predictor of aggressivity in young adults. Loneliness and depression were found } \\
\text { to be positive predictors for aggressivity in young adults, while self-conception was } \\
\text { found to be a negative predictor. }\end{array}$} \\
\hline $\begin{array}{l}\text { 12. Yuan and } \\
\text { Hesketh, } \\
\text { (2019). July- } \\
\text { September } 2018\end{array}$ & 2987 wome & $\begin{array}{l}\text { Partly Conflict Tactics Scale-2 (CTS-2), } \\
\text { partly Composite Abuse Scale, The Center } \\
\text { for Epidemiologic Studies Depression } \\
\text { Scales (CES-D) (paper and electronic) }\end{array}$ & \\
\hline $\begin{array}{l}\text { Findings } \\
\text { (psychological } \\
\text { factors) }\end{array}$ & \multicolumn{3}{|c|}{$\begin{array}{l}\text { Prevalence of depression: } 65.8 \% \text { experienced psychological violence, } 69.5 \% \text { physical } \\
\text { violence, } 75.8 \% \text { sexual violence. }\end{array}$} \\
\hline $\begin{array}{l}\text { 13. Pelletier et } \\
\text { al., (2016). } \\
2011-2012\end{array}$ & $\begin{array}{l}441 \text { students under } 35 \\
\text { (index of } 20-35 \mathrm{~kg} / \mathrm{m} 2 \text { ), } \\
\text { community colleges } \\
\text { Minnesota, USA }\end{array}$ & $\begin{array}{l}\text { Cross-sectional, quantitative study } \\
\text { Shorr height boards (Irwin Shorr, Olney, } \\
\text { MD) and Tanita scales (Tanita TBF-300A } \\
\text { Body Composition Analyzer, Arlington } \\
\text { Heights, Cohen Perceived Stress Scale }\end{array}$ & \\
\hline $\begin{array}{l}\text { Findings } \\
\text { (psychological } \\
\text { factors) }\end{array}$ & \multicolumn{3}{|c|}{$\begin{array}{l}\text { High levels of stress have been associated with a high prevalence of overweight and } \\
\text { obesity. }\end{array}$} \\
\hline
\end{tabular}




\section{Table 5}

Analysis of studies that researched only risky behaviors in students

\begin{tabular}{|c|c|c|c|}
\hline References & Sample & Methodology & $\begin{array}{l}\text { Behaviors } \\
\text { approached } \\
\text { through the risk } \\
\text { dimension }\end{array}$ \\
\hline $\begin{array}{l}1 . \\
\text { Choudhry } \\
\text { et al., } \\
(2014)\end{array}$ & $\begin{array}{l}1954 \text { students, under 22, } \\
\text { over 22, University of } \\
\text { Mbarara, Uganda }\end{array}$ & $\begin{array}{l}\text { Cross-sectional study } \\
\text { self-administered questionnaire, } 132 \\
\text { items, English language }\end{array}$ & $\begin{array}{l}\text { alcohol } \\
\text { consumption, } \\
\text { sexual activity }\end{array}$ \\
\hline
\end{tabular}

(2014).

2010

Findings Alcohol consumption has been associated with 2 or more sexual partners in the last year (M, F).

(behaviors) Significant associations between: alcohol consumption in general, alcohol consumption in relation to sexual activity and alcohol consumption at the last sexual intercourse with having multiple sexual partners. Inconsistency in condom use with new sexual partners was significant for men who consumed alcohol in connection with sexual activity. For women who drank alcohol frequently in connection with sexual activity, the risk of inconsistency in condom use was 2 times higher.

$\begin{array}{llll}\begin{array}{l}\text { 2. Kilwein } \\ \text { and Looby, }\end{array} & \begin{array}{l}\text { 108 students, 18-24 years } \\ \text { old (average 19.9), }\end{array} & \begin{array}{l}\text { Cross-sectional study } \\ \text { Daily Drinking Questionaire (DDQ); }\end{array} & \begin{array}{l}\text { alcohol } \\ \text { consumption, } \\ \text { (2018). }\end{array} \\ \begin{array}{ll}\text { Midwestern US, 90 female } \\ (83.3 \%)\end{array} & \begin{array}{l}\text { Drinking Motives Questionnaire - } \\ \text { Revised (DMQ-R); Cognitice Appraisal } \\ \text { of Risky Events Revised (CARE-R) - } \\ \text { Risky sexual Activity Scale }\end{array} & \\ & & \end{array}$

Findings $\quad$ Risky sexual behavior more often when consuming alcohol. Reported risky sexual activities: (behaviors) unprotected sex, sexual coercion, sex with unknown partners. The trend towards risky sexual behavior increases by $10.4 \%$ with each unit of social reasons. Individuals with strong reasons for strengthening/intensifying (validation) were prone to risky sex (regardless of alcohol level).

\begin{tabular}{|c|c|c|c|}
\hline $\begin{array}{l}\text { 3. Looby et } \\
\text { al., (2019). }\end{array}$ & $\begin{array}{l}2039 \text { (out of } 7307) \\
\text { students, } 18-24 \text { years old } \\
\text { (average } 19.79 \text {, at } 10 \\
\text { universities in } 10 \text { US } \\
\text { states, } 1485 \text { female } \\
(72.83 \%)\end{array}$ & $\begin{array}{l}\text { Cross-sectional study } \\
\text { online questionnaire; informed consent, } \\
\text { credit for participation in scientific } \\
\text { research, M-DMQ-R, Protective } \\
\text { Behavioral Strategies Scale-20 (PBSS- } \\
\text { 20); DDQ; CARE-R-FOI; }\end{array}$ & $\begin{array}{l}\text { alcohol } \\
\text { consumption, } \\
\text { sexual activity }\end{array}$ \\
\hline $\begin{array}{l}\text { Findings } \\
\text { (behaviors) }\end{array}$ & \multicolumn{3}{|c|}{$\begin{array}{l}\text { Alcohol consumption mediates the association between social reasons and risky sexual behavior, } \\
\text { between reasons for reinforcement and risky sexual behavior. Risky sexual activities: } \\
\text { unprotected sex, sexually transmitted diseases, multiple sexual partners, risky sexual partners, } \\
\text { sexual coercion. Reduction of serious harm (negative effects) mediates the association between } \\
\text { social reasons and risky sexual behavior; Reduction of serious harm mediates the association } \\
\text { between reasons for reinforcement and risky sexual behavior; }\end{array}$} \\
\hline
\end{tabular}

\section{Acknowledgements}

This study is part of the doctoral research project entitled "Psychological factors involved in risk behaviors in Romanian students", PhD. Student LUNGU Mihaela, coordinated by PhD. Cornelia Rada, at the School of Advanced Studies of the Romanian Academy, "Constantin Rădulescu-Motru" Institute of Philosophy and Psychology, Department of Psychology, Romanian Academy, Bucharest, Romania. 


\section{References}

1. Agardh, A., Cantor-Graae, E., \& Ostergren, P. O. (2012a). Youth, sexual risk-taking behavior, and mental health: a study of university students in Uganda. International journal of behavioral medicine, 19(2), 208-216. https://doi.org/10.1007/s12529-011-9159-4

2. Agardh, A., Tumwine, G., Asamoah, B. O. \& Cantor-Graae, E. (2012b). The invisible suffering: sexual coercion, interpersonal violence, and mental health--a cross-sectional study among university students in south-western Uganda. PloS one,7(12), e51424. https://doi.org/10.1371/journal.pone.0051424

3. Ahmed, F., Al-Radhwan, L., Al-Azmi, G. Z. S., \& Al-Beajan, M. (2014). Association between Stress and Dietary Behaviours among Undergraduate Students in Kuwait: Gender Differences. Journal of Nutrition and Health Sciences, 1(1). doi: 10.15744/2393-9060.1.104

4. Aluja, A., Lucas, I., Blanch, A., \& Blanco, E. (2019). Personality and disinhibitory psychopathology in alcohol consumption: A study from the biological-factorial personality models of Eysenck, Gray and Zuckerman. Personality and Individual Differences, 142, 159165. https://doi.org/10.1016/j.paid.2019.01.030

5. Bonsaksen, T., \& Lerdal, A. (2012). Relationships between Physical Activity, Symptoms and Quality of Life among Inpatients with Severe Mental Illness. British Journal of Occupational Therapy, 75(2), 69-75. https://doi.org/10.4276/030802212X13286281651036

6. Breet, E., Seedat, S., \& Kagee, A. (2019). Posttraumatic Stress Disorder and Depression in Men and Women Who Perpetrate Intimate Partner Violence. Journal of interpersonal violence, 34(10), 2181-2198. https://doi.org/10.1177/0886260516660297

7. Bryan, J. L., Baker, Z. G., \& Tou, R. Y. (2017). Prevent the blue, be true to you: Authenticity buffers the negative impact of loneliness on alcohol-related problems, physical symptoms, and depressive and anxiety symptoms. Journal of Health Psychology, 22(5), 605-616. https://doi.org/10.1177/1359105315609090

8. Carney, B., White, J., Xu, X., Sunil, T., Daniels, C., Byrne, M., ..., \& Okulicz, J. F. (2019). Relationship between depression and risk behaviors in a US Military population with HIV infection. AIDS care, 31(9), 1152-1156. https://doi.org/10.1080/09540121.2019.1595522

9. Cazan, A. -M., \& Truța, C. (2015). Stress, resilience and life satisfaction in college students. Social Research and Intervention Magazine 48, 95-108, Expert Projects Publishing House. https://www.rcis.ro/images/documente/rcis48_08.pdf

10. Choudhary, E., Smith, M., \& Bossarte, R. M. (2012). Depression, anxiety, and symptom profiles among female and male victims of sexual violence. American journal of men's health, 6(1), 28-36. https://doi.org/10.1177/1557988311414045

11. Choudhry, V., Agardh, A., Stafström, M., \& Östergren, P. O. (2014). Patterns of alcohol consumption and risky sexual behavior: a cross-sectional study among Ugandan university students. BMC Public Health 14, 128. https://doi.org/10.1186/1471-2458-14-128

12. Costa, M., Barré, T., Coste, M., Yaya, I., Berenger, C., Tanti, M., ..., \& Carrieri, P. M. (2020). Screening and care for alcohol use disorder in France: expectations, barriers and levers using a mixed-methods approach. BMC Public Health, 20, 358. https://doi.org/10.1186/s12889020-08495-X

13. Davis, K. C., Kiekel, P. A., Schraufnagel, T. J., Norris, J., George, W. H., \& Kajumulo, K. F. (2012). Men's Alcohol Intoxication and Condom Use During Sexual Assault Perpetration. Journal of Interpersonal Violence, 27(14), 2790-2806. https://doi.org/10.1177/0886260512438277 
14. Dobson, K. S., Ahnberg Hopkins, J., Fata, L., Scherrer, M., \& Allan, L. C. (2010). The Prevention of Depression and Anxiety in a Sample of High-Risk Adolescents: A Randomized Controlled Trial. Canadian Journal of School Psychology, 25(4), 291-310. https://doi.org/10.1177/0829573510386449

15. Fahrenberg, J., Hampel, R., \& Selg, H., (2001). Freiburger Personlichkeitsinventar, adaptat în România de Pitariu, H. P. și Iliescu, D. (2007) [Personality inventory Freiburg adapted for Romania by Pitariu, H. P. \& Iliescu, D. (2007) - (FPI-R)]. Cluj-Napoca: Editura Sinapsis Publishing Projects, distribuit sub licență de D\&D Consultantag Group, SRL, București:Testcentral [Sinapsis Publishing Projects, distributed under licence by D\&D Consultantag Group, SRL, București:Testcentral]

16. Faludi, C. (2018). Consequences of Intimacy and Violence in the Couple Relationships of Young Romanians on Their Future Life Plans. In de Montlibert, C., Radu, D. and Zamfira, A. (eds.), Gender in Focus: Identities, Codes, Stereotypes and Politics (pp. 226-249). Berlin \& Toronto: Barbara Budrich Publishers

17. Foli, K. J., South, S. C., Lim, E., \& Hebdon, M. (2012). Maternal Postadoption Depression, Unmet Expectations, and Personality Traits. Journal of the American Psychiatric Nurses Association, 18(5), 267-277. https://doi.org/10.1177/1078390312457993

18. Garthe, R. C., Sullivan, T. N., \& Behrhorst, K. L. (2018). A Latent Class Analysis of Early Adolescent Peer and Dating Violence: Associations With Symptoms of Depression and Anxiety. Journal of Interpersonal Violence. 36(5-6), 2031-2049. https://doi.org/10.1177/0886260518759654

19. Glasier, A., Gülmezoglu, A. M., Schmid, G. P., Moreno, C. G., \& Van Look, P. F. (2006). Sexual and reproductive health: a matter of life and death. Lancet (London, England), 368(9547), 1595-1607. https://doi.org/10.1016/S0140-6736(06)69478-6

20. Guruprasad, S., Ramakrishnan, K. S., \& Shah, P. (2015). Prevalence of depression, anxiety and stress in patients with mechanical low back pain. International Journal of Therapies and Rehabilitation Research, 4, 67-72. doi: 10.5455/ijtrr.00000068

21. Hebdon, M., Foli, K., South, S., \& Lim, E. (2012). Personality Traits, Unmet Expectations, and Depressive Symptoms in Adoptive Mothers. Western Journal of Nursing Research, 34(8), 1070-1071. https://doi.org/10.1177/0193945912453688

22. Kalina, O., Madarasova Geckova, A., Klein, D., Jarcuska, P., Orosova, O., Dijk, J.P., \& Reijneveld, S. A. (2011). Psychosocial factors associated with sexual behaviour in early adolescence. The European journal of contraception \& reproductive health care: the official journal of the European Society of Contraception. 16, 298-306. https://doi.org/10.3109/13625187.2011.586076;

23. Kilwein, T. M., \& Looby, A. (2018). Predicting risky sexual behaviors among college student drinkers as a function of event-level drinking motives and alcohol use. Addictive Behaviors, 76, 100-105. https://doi.org/10.1016/j.addbeh.2017.07.032

24. Lalinec-Michaud, M., \& Engelsmann, F. (1984). Anxiety, Fears and Depression Related to Hysterectomy. The Canadian Journal of Psychiatry, 30(1), 44-47. https://doi.org/10.1177/070674378403000108

25. Lloyd, C. S., af Klinteberg, B., \& DeMarinis, V. (2017). An Assessment of Existential Worldview Function among Young Women at Risk for Depression and Anxiety-A MultiMethod Study. Archive for the Psychology of Religion, 39(2), 165-203. https://doi.org/10.1163/15736121-12341337 
26. Looby, A., Bravo, A. J., Kilwein, T. M., Zimmerman, L., Pearson, M. R., \& Protective Strategies Study Team (2019). Alcohol-related protective behavioral strategies as a mediator of the relationship between drinking motives and risky sexual behaviors. Addictive behaviors, 93, 1-8. https://doi.org/10.1016/j.addbeh.2019.01.009

27. Lovibond, S. H., \& Lovibond, P. F. (1995). DASS: manual pentru scalele de depresie, anxietate şi stres: DASS 21-R, adaptat în România de Perțe, A. coord. Albu, M. (2011). DASS 21-R [DASS. Manual for the Depression Anxiety Stress Scales, School of Psychology, University of New South Wales, Sydney, Australia. Adapted for Romania by Perțe, A. coord. Albu, M. (2011). DASS 21-R]. Cluj-Napoca: Editura ASCR [Cluj-Napoca: ASCR Publishing House]

28. Maina, B. W., Orindi, B. O., Osindo, J., \& Ziraba, A. K. (2020). Depressive symptoms as predictors of sexual experiences among very young adolescent girls in slum communities in Nairobi, Kenya. International journal of adolescence and youth, 25(1), 836-848. https://doi.org/10.1080/02673843.2020.1756861

29. Masters, M. R., Zimmer-Gembeck, M. J., \& Farrell, L. J. (2019). Transactional Associations Between Adolescents' Emotion Dysregulation and Symptoms of Social Anxiety and Depression: A Longitudinal Study. The Journal of Early Adolescence, 39(8), 1085-1109. https://doi.org/10.1177/0272431618806053

30. McDougall, E. E., Langille, D. B., Steenbeek, A. A., Asbridge, M., \& Andreou, P. (2019). The Relationship Between Non-Consensual Sex and Risk of Depression in Female Undergraduates at Universities in Maritime Canada. Journal of Interpersonal Violence, 34(21-22), 4597-4619. https://doi.org/10.1177/0886260516675468

31. Monu, A. M., Porumb-Andrese, E., Toader, M. P., Loghin, L., Gheucă-Solovăstru, L., \& Vâță D. (2020). Epidemiological aspects of syphilis, Medical-Surgical Journal - Rev. Med. Chir. Soc. Med. Nat., 124, 307-312. Iași. Retrieved December 15, 2020, from https://www.revmedchir.ro/index.php/revmedchir/article/view/2123

32. Mutalik, N., Moni, S., Choudhari, S., \& Bhogale, G. (2016), Depression, Anxiety, Stress among College Students in Bagalkot: A College Based Study. International Journal of Indian Psychology, 3(4). doi: 10.25215/0304.210

33. Ngo, Q. M., Ramirez, J. I., Stein, S. F., Cunningham, R. M., Chermack, S. T., Singh, V., \& Walton, M. A. (2018). Understanding the Role of Alcohol, Anxiety, and Trait Mindfulness in the Perpetration of Physical and Sexual Dating Violence in Emerging Adults. Violence Against Women, 24(10), 1166-1186. https://doi.org/10.1177/1077801218781886

34. Pelletier, J. E., Lytle, L. A. \& Laska, M. N., (2016). Stress, Health Risk Behaviors, and Weight Status Among Community College Students. Health Education \& Behavior, 43(2), 139-144. https://doi.org/10.1177/1090198115598983

35. Petrova, M., Martinez, C. R., Jean-Jacques, J., McClure, H. H., Pantin, H., Prado, G. \& Schwartz, S. J. (2019). Mind the Gap: Bridging the Divide Between Current Binge Drinking Prevention and the Needs of Hispanic Underage Emerging Adults. SpringerLink, Prevention Science 20, 1114-1124. https://doi.org/10.1007/s11121-019-01026-0

36. Rada, C. (2014). Violence against women by male partners and against children within the family: prevalence, associated factors, and intergenerational transmission in Romania: a cross-sectional study. BMC Public Health 14, 129. doi:10.1186/1471-2458-14-129

37. Rada, C., \& Ispas, A. T. (2016). Alcohol consumption and accentuated personality traits among young adults in Romania: a cross-sectional study. Substance Abuse Treatment, Prevention, and Policy, 11(36). doi: 10.1186/s13011-016-0080-3 
38. Rada, C. (2020). Factors Associated with Depression in Middle-Aged and Elderly People in Romania. Psichologija, 61, 33-50. 10.15388/Psichol.2020.14

39. Schulenberg, J., Johnston, L., O'Malley, P., Bachman, J., Miech, R., \& Patrick, M. (2019). Monitoring the Future national survey results on drug use, 1975-2018: Volume II, college students and adults ages 19-60, Ann Arbor: Institute for Social Research, The University of Michigan. http://monitoringthefuture.org/pubs.html\#monographs

40. Shwartz, N., O’Rourke, N., \& Daoud, N. (2020). Pathways Linking Intimate Partner Violence and Postpartum Depression Among Jewish and Arab Women in Israel. Journal of Interpersonal Violence. https://doi.org/10.1177/0886260520908022

41. Soleimani, M., Pahlevan Sharif, S., Bahrami, N., Yaghoobzadeh, A., Allen, K.A., \& Mohammadi, S. (2017). The relationship between anxiety, depression and risk behaviors in adolescents. International journal of adolescent medicine and health, 31. doi: 10.1515/ijamh2016-0148

42. Stahre, M., Roeber, J., Kanny, D., Brewer, R. D., \& Zhang, X. (2010). Contribution of Excessive Alcohol Consumption to Deaths and Years of Potential Life Lost in the United States. Prev Chronic Dis, 11. doi: http://dx.doi.org/10.5888/pcd11.130293

43. Tutino, J. S., Shaughnessy, K., \& Ouimet, A. J. (2018). Looking at the bigger picture: Young men's sexual health from a psychological perspective. Journal of Health Psychology, 23(2), 345-358. https://doi.org/10.1177/1359105317733321

44. ul Haq, M. A., Irum Sajjad Dar, I. S., Aslam, M., \& Mahmood, Q. K. (2018). Psychometric study of depression, anxiety and stress among university students. J Public Health, 26, $211-$ 217. https://doi.org/10.1007/s10389-017-0856-6

45. Vencill, J. A., Tebbe, E. A., \& Garos, S. (2015). It's Not the Size of the Boat or the Motion of the Ocean: The Role of Self-Objectification, Appearance Anxiety, and Depression in Female Sexual Functioning. Psychology of Women Quarterly, 39(4), 471-483. https://doi.org/10.1177/0361684315587703

46. Wolff, K. T., \& Baglivio, M. T. (2017). Adverse Childhood Experiences, Negative Emotionality, and Pathways to Juvenile Recidivism. Crime \& Delinquency, 63(12), 14951521. https://doi.org/10.1177/0011128715627469

47. Yang, B., Zhang, J., Qi, Y., Wang, P., Jiang, R., \& Li, H. (2017). Assessment on Occurrences of Depression and Anxiety and Associated Risk Factors in the Infertile Chinese Men. American Journal of Men's Health, 767-774. https://doi.org/10.1177/1557988317695901

48. Yavuzer, Y., Albayrak, G., \& Kılıçarslan, S. (2019). Relationships Amongst Aggression, SelfTheory, Loneliness, and Depression in Emerging Adults. Psychological reports, 122(4), 1235-1258. https://doi.org/10.1177/0033294118784866

49. Yuan, W., \& Hesketh, T. (2019). Intimate Partner Violence and Depression in Women in China. Journal of interpersonal violence, Advance online publication. https://doi.org/10.1177/0886260519888538

50. ***American Psychiatric Association (2016). DSM-5 Manual de Diagnostic și Clasificare Statistică a Tulburărilor Mintale, 5. [DSM-5 Diagnostic and statistical manual of mental disorders (5th ed.)(2013)]. Bucharest: Editura medicală Calisto [Calisto medical publishing house]

51. ***European Centre for Disease Prevention and Control (2019) Syphilis and congenital syphilis in Europe. A review of epidemiological trends (2007 2018) and options for response. Retrieved April 13, 2020, from https://www.ecdc.europa.eu/en/publications-data/syphilisand-congenital-syphilis-europe-review-epidemiological-trends-2007-2018 
52. ***Ministerul Sănătăţii, Institutul Naţional de Sănătate Publică, Centrul Naţional de Evaluare și Promovare a Stării de Sănătate și Centrul Regional de Sănătate Publică, Sibiu [Romanian Ministry of Health, Romanian National Institute of Public Health, Romanian National Center for Health Assessment and Promotion and the Regional Center for Public Health,Sibiu](2019). Analiză de situație [Situation analysis]. Retreived August 12, 2020, from https://www.insp.gov.ro/index.php/informatii-publice/send/7-informatii-publice/722raport-insp-2018

53. ***World Health Organization. (2019). Romania - Alcohol Consumption: Levels and Patterns. $\quad$ Retreived May 15, 2020, from https://www.who.int/substance_abuse/publications/global_alcohol_report/profiles/rou.pdf?u $\mathrm{a}=1$

54. ***World Health Organization. (2018). Global status report on alcohol and health 2018. $\begin{array}{llll}\text { Retrieved May 15, 2020, from } & \text { Ma }\end{array}$ https://www.who.int/substance_abuse/publications/global_alcohol_report/en/ 